\title{
Relation between Observed and Perceived Traffic Noise and Socio-Economic Status in Urban Blocks of Different Characteristics
}

\author{
Malte von Szombathely ${ }^{1, *(1)}$, Myriam Albrecht ${ }^{1}$, Jobst Augustin ${ }^{2}$, Benjamin Bechtel ${ }^{1}$ (D), \\ Isabel Dwinger ${ }^{1}$, Philine Gaffron ${ }^{3}$, Anne Caroline Krefis ${ }^{2}$, Jürgen Oßenbrügge ${ }^{1}$ and \\ Anke Strüver ${ }^{1}$ \\ 1 Institute of Geography, Centrum für Erdsystemforschung und Nachhaltigkeit (CEN), Universität Hamburg, \\ Bundesstr. 55, 20146 Hamburg, Germany; myriam.albrecht@uni-hamburg.de (M.A.); \\ benjamin.bechtel@uni-hamburg.de (B.B.); isabel.dwinger@studium.uni-hamburg.de (I.D.); \\ juergen.ossenbruegge@uni-hamburg.de (J.O.); anke.struever@uni-hamburg.de (A.S.) \\ 2 Institute for Health Services Research in Dermatology and Nursing (IVDP), University Medical Center \\ Hamburg-Eppendorf (UKE), Martinistr. 52, 20246 Hamburg, Germany; jo.augustin@uke.de (J.A.); \\ a.krefis@uke.de (A.C.K.) \\ 3 Institute for Transport Planning and Logistics, Hamburg University of Technology (TUHH), 21071 Hamburg, \\ Germany; p.gaffron@tuhh.de \\ * Correspondence: malte.szombathely@uni-hamburg.de
}

Received: 20 December 2017; Accepted: 24 February 2018; Published: 28 February 2018

\begin{abstract}
Living in cities offers many benefits and thus more and more people are living in urban areas. However, the concentration of human activities also creates environmental stressors with severe influence on people's health and well-being. Noise is an environmental stressor with known health impact. Despite this, studies investigating small-scale difference in noise exposure and annoyance are lacking. Against this background, this case study investigates environmental justice empirically, focusing on the distribution of road traffic noise and its perception in Hamburg, Germany. The study outlines a methodological approach that takes into account subjective and objective measures of exposure in small-scale residential blocks. The results show that annoyance by noise is clearly related to noise emission. Moreover, different groups are affected by noise pollution in our study area unequally. In particular, younger people and people with lower socio-economic status have higher probabilities to be affected by noise. Additionally, it emerged that participants reporting higher levels of annoyance from noise are on average younger than those feeling less annoyed. Overall, these results show that the current legal noise limits applicable to residential planning processes in German cities are not sufficient to prevent substantial annoyance effects in residential populations.
\end{abstract}

Keywords: Environmental Justice; Environmental Equity; road traffic noise; noise perception; noise annoyance; Hamburg

\section{Introduction}

Vibrant and densely populated cities are often considered to be one of the most preferred urban environments because they offer opportunities for a creative economy, social life, outdoor activities and entertainment amongst others. Yet life in such cities is also influenced by different types of stressors, such as noise, air pollution, light pollution and density. Consequently, individual coping capacities are important for mitigating the effects of such stressors. This can include residential location choices, the insulation and ventilation of indoor spaces or regularly accessing rest zones and protected areas. Preventative as well as curative health measures belong to coping mechanisms, too. Clearly, both the stressors and the coping capacity are distributed unequally. Deprived social groups are often 
specifically exposed to single and multiple stressors to an extent which does not fulfill the aims of a just city and may even lead to serious health problems (Section 2.2).

Focusing on exposure to noise, this paper aims to understand the relations between the stressor noise, its perceived and qualitative characteristics, and the socioeconomic status of urban dwellers. This results in three research questions:

(1) Which socio-economic groups mainly live in noisy locations (when looking at small-scale residential areas)?

(2) Is there a correlation between noise exposure and the subjective perception of this stressor?

(3) Is there a relation between perception of traffic noise and socio-economic characteristics?

Conceptually, we frame these questions by Environmental Justice. This will be discussed in detail in the following section and conclusions for our research design will be drawn. The case study addresses the research questions using small-scale urban blocks of different characteristics in Hamburg, Germany. The paper is structured in three parts: firstly, we outline conceptual issues of the debate, including a brief review of noise-related research in German and European cities. Secondly, we select a mix of methods that allows us to differentiate issues of Environmental Justice on a micro scale. Finally, we present results of the case study and link these to the conceptual debate in order to define future research tasks.

\section{Conceptual Issues of Environmental Justice and Noise Exposure in Urban Areas}

\subsection{Theoretical Approaches to Environmental Justice}

In the European context, Environmental Justice (EJ) as a conceptual framework focuses on the unequal distribution of environmental benefits and harms in general and on spatial disparities in human exposures to environmental stressors such as various pollutants and noise, in particular. In this context, it is commonly accepted that socio-economically disadvantaged people are often more exposed than privileged ones [1-3]. Early prominent EJ studies on Louisiana's 'Cancer Alley' [4,5] or landfills in Texas [6], for example, found that petrochemical industries and landfills are regularly located close to Black neighborhoods and economically poor communities, causing severe health issues.

Maschewsky was one of the first to apply the concept of EJ in Germany during the 1980s [7]. Maschewsky marks the transition to a "new" approach to human health that includes the concept of justice to address the social inequality of environmental risks [8]. Today, the German Environment Agency has also included this perspective in its political agenda: "Health problems resulting from environmental problems are unequally distributed in Germany. Social and environmental epidemiological studies of recent years indicate that the socioeconomic status and the cultural/ethnic background in Germany influence where one lives, whether and to what extent children, adolescents and adults are burdened by environmental stressors" (own translation) [9]. Consequently, it is nowadays a common perception that EJ and public health are related [10-14]. Nonetheless, little primary data has been collected to support these claims. This was one major motivation for the research presented in this paper.

According to Walker, most approaches of studying inequalities correspond to a descriptive and distributional approach of EJ. In the meantime, normative approaches have emerged, too, especially when studying justice [15]. Consequently, distribution is seen as just one aspect of EJ. Especially, Young criticizes the "distributive paradigm" within theories of justice. She requests focusing on power dynamics, on deeper structural relations and also on institutional conditions [16,17]. Maschewsky refers to this as 'equality of opportunity' and, moreover, considers the right to participate in the decisions on protection and transformation as additional important factors for justice $[7,18]$. Consequently, distributional aspects of justice cannot be studied with reference to data on social characteristics and spatial context only, but should also be approached in terms of including the perceptions of environmental stressors by those concerned $[19,20]$. We have included the latter 
perspective in the conceptualization of our research. Yet, access to power structures or evaluation of participation opportunities in the city's planning is not possible through our research design (see Section 3).

As studies on EJ predominantly follow a descriptive approach, quantitative approaches are often applied for analyzing correlations between social parameters and the distribution of environmental stressors. Therefore, most descriptive EJ studies make use of GIS analysis as well as statistical applications.

\subsection{Noise as Major Urban Stressor}

In the urban context, noise is one of several environmental stressors influencing health-related urban well-being (UrbWellth) [21-23]. A number of studies have shown the link between noise and health outcomes such as cardiovascular [22-24] or respiratory diseases [25-27], demonstrating therefore that noise is a major stressor in the general context of health-related urban well-being (UrbWellth) [21].

Individual noise sensitivities differ, yet noise below $30 \mathrm{~dB}(\mathrm{~A})$ is defined to be at a no-observedadverse-effect level (NOAEL) as sleep is not disturbed by noise below $30 \mathrm{~dB}(\mathrm{~A})$ [28]. Upper noise limits for industry in built-up areas such as the city of Hamburg are set by the German 'TA Lärm' for "urban areas" [29]. Daytime noise immission limits (6:00-22:00 h) are set at $L_{e q} 63 \mathrm{~dB}(\mathrm{~A})$. A limit of $45 \mathrm{~dB}(\mathrm{~A})$ is set for the night (22:00-6:00 h).

The "Verkehrslärmschutzverordnung" (Traffic Noise Protection Ordinance), relevant for planning purposes, on the other hand, clearly sets higher limits: The noise immission limits are $64 \mathrm{~dB}(\mathrm{~A})$ for daytime and $54 \mathrm{~dB}(\mathrm{~A})$ at night (22:00-6:00 h) for inner city areas [30]. Therefore, especially the limits set for nighttime noise considerably exceed the recommendations of the WHO [28]. Where "TA Lärm" provides standards for built-up areas and immissions by businesses and industries, "Verkehrslärmschutzverordnung" is the legal framework for traffic-induced noise when planning new development projects.

Since in urban areas, environmental noise is mainly induced by road traffic [31,32], we focus on this stressor in this study.

\subsection{Methodological Considerations and Recent Studies on Noise}

According to Dale et al., noise pollution was underrepresented in EJ research until only a few years ago [33]. However, in recent years several studies focused on connections between traffic-induced noise and socio-economic variables [34-37]. In the following we highlight selected examples relevant for our own work. Also, they all take the perspective of distributive EJ [38].

One of the biggest data collections on EJ in Germany, the Umweltatlas (environmental atlas) for the city of Berlin, originally started with a simple cartographic display of various environmental issues [39]. At first, it did not refer to possible (negative) health impacts on the population or issues of EJ. The EJ board (appointed in 2008) eventually combined data on the environmental stressors in Berlin to establish a simple additive connection between different environmental stressors and the respective residential quarters (small-scale areas). It thus became possible to identify neighborhoods which were highly affected by both environmental and social disadvantages. However, as this resource is intended as a tool to support planning decisions, it does not enquire into underlying causes; these were partly addressed by Lakes et al. In their discussion of EJ in Berlin [40].

In Dortmund, Flacke et al. [41] also focused on the relationships between social groups and four environmental stressors, namely green spaces, noise and two different air pollutants $\left(\mathrm{NO}_{2}, \mathrm{PM}_{10}\right)$. Again, hotspots of injustice were identified through intersecting environmental and socio-economic stressors. In contrast to the 'Umweltatlas', Flacke et al. worked at neighborhood scale (larger-scale areas) which they consider the typical scale for urban planning measures. Interestingly, no significant correlations between noise exposure and social context were found. For Rome, a longitudinal study by Cesaroni et al. even detected that mostly wealthier social groups live in areas affected by traffic 
noise [42]. This is explained by the fact that the denser, busier center is characterized by an older residential population with a higher socio-economic status than the rest of Rome.

Dale et al. explicitly studied the distribution of noise exposure among disadvantaged social groups on the Island of Montreal, Canada, and contextualized the results by pointing out that wealthier people have choices where to live in a city [33]. In their study, eight social indicators were correlated with the outdoor summer noise level ( $L_{a e q} 24 \mathrm{~h}$, see below) simulated in a $20 \mathrm{~m}$ resolution for Montreal. All associations in their bi-variate model show a moderate and positive linear correlation of noise exposure and social deprivation, with the strongest correlation for median household income.

Overall, socio-economic status (often defined via income, education and different additional variables) has been found to be correlated with outdoor noise pollution in a variety of socio-spatial contexts. However, where significant correlations were found, they generally only explained a small proportion of the variance. Moreover, the direction of this relationship is partly contradictory; while old, centralizing cities (such as Rome [42] or Paris [36]) have highly attractive inner cities, where the pull factors seem to outweigh the environmental stressors [43], a linear distance gradient with an opposite direction is often detectable in North American cities [33,44,45] or fast-growing Asian Cities [46]. We argue that this is partly because the chosen scales suppress small-scale differences, which are highly relevant due to the small-scale variability of the stressor. For example, Moreno-Jímenez et al. found the scale of the entire municipal area (large-scale area, used due to public data availability) as too coarse-grained [47]. Additionally, access to public data sets is often restricted due to data protection regulations. Flacke et al. also critically discuss their results and the quality of the data used based on the example of exposure and found aggregated environmental data incapable of linking levels of exposure to where people live within a neighborhood [41].

To overcome these shortcomings, complement previous studies and broaden the available primary data, we have chosen an empirical research design using a survey, observations and model data within several urban blocks in Hamburg (see Section 3.1 for details). Moreover, a number of issues have been flagged in the past, which need to be considered when using proximity measures as an indicator for exposure to environmental hazards or stressors. The approach taken in our study overcomes the main methodological risks as follows:

- boundary effects: EJ studies often either use public statistical units (such as census blocks or ZIP code areas) or buffers around the origin of environmental stress factors (circular for point sources, linear for e.g., roads) to define the populations affected, which can lead to incorrect assignment of affected population $[48,49]$. We address this by using the results of a noise propagation model coupled with measurements and furthermore only comparing differences in affectedness among households living within our chosen study areas.

- Modifiable areal unit problem: The areal unit chosen for spatial analysis has repeatedly also been flagged as a potential source of uncertainty in EJ studies as the strength of association between socioeconomic and environmental variables often changes with scale. This phenomenon is known as the Modifiable Areal Unit Problem (MAUP). For instance, Mennis, Schweitzer and Stephenson (Jr.) illustrated the MAUP phenomenon by showing how using larger U.S. censusor ZIP code-based units show obscure variations and differences existing between smaller-scale units [50,51]. In this study we use socio-economic data from a household questionnaire which is not aggregated to larger units. The noise data originates from a dispersion model, which depicts $\mathrm{dB}(\mathrm{A})$ for $10 \times 10 \mathrm{~m}$ raster cells. We thus do not consider MAUP to be a problem.

- Spatial autocorrelation is another important consideration in EJ analysis. According to Tobler's first law of geography “(...) everything is related to everything else, but near things are more related than distant things" [52], such correlations can be expected in EJ analyses, which are based on the assumption that neither environmental burdens nor the population are randomly or evenly distributed in space. Spatial autocorrelation generally renders the application of general linear regression models inappropriate, since they rely on the assumption of independent residuals. However, in this study we test for correlations using Spearman's Rho which is non-parametric. 
One of the main restrictions of EJ studies often lies in the spatial resolution of the available data. In a European context, this changed to some degree in relation to noise as a stressor with the introduction of mandatory strategic noise mapping through EU Directive 2002/49/EC. The data calculated for the strategic noise map of Hamburg are used in this study [53,54]. With regard to the people affected, we have overcome this shortcoming by conducting a targeted household questionnaire study.

While international EJ studies have predominantly used measured or modelled parameters to characterise exposure levels, studies in Germany often relied on secondary data sets, containing information on respondents' self-assessed exposure levels as opposed to objective measures [55-57]. One notable exception was presented by Köckler et al., who showed that, in general, perceived exposure was strongly correlated with objective exposure measures [58]. Looking at hedonic evaluation of property in relation to traffic noise, Baranzini, Schaerer and Thalmann found a high correlation between measured, resp. extrapolated and perceived noise levels [59]. Neither of these studies investigated, though, whether socio-economic variables are in any way related to a variation in perception of comparable noise levels. Riedel et al. stated that noise exposure predicts noise annoyance only insufficiently [34]. However, the integration of socio-economic variables led to mixed results (see Section 4.4 for our results).

Following these theoretical and methodological considerations, the research design for the case study was developed as described in the following section. Road noise was chosen as environmental stressor due to its high relevance in Hamburg, especially due to the amount of motorized traffic [60].

\section{Materials and Methodology}

\subsection{Study Areas and Data Acquisition}

We conducted a household survey to collected primary data on perception at a high spatial resolution in urban blocks and thus account for small-scale differences in exposure. Moreover, noise measurements and modelled data were taken to represent the variation in noise pollution. The survey comprised living conditions and evaluation of the residential area (satisfaction with infrastructure and assets, future wishes), mobility behavior (means of transport used, duration, reasons for use), health $[61,62]$ and questions on annoyance due to environmental stressors (annoyance by noise, air pollution, heat). The survey also included several questions on the socio-economic characteristics of the respondents (education, income, occupation, age, etc.). The complete questionnaire (in German) can be obtained from the corresponding author. To increase the response rate of the survey, the following measures were implemented: restriction to 6 pages, postage-paid return envelope, advance notice of the survey, incentive for the participants [63,64].

For our questionnaire, different assessment instruments related to health were evaluated [61,65-68]. Additionally, several questions were derived from the UrbWellth model [21]. The whole questionnaire was repeatedly pre-tested. It comprises 51 questions in total, but only eight are analyzed in this study (see Table 1 and Section 4). In 24 study areas (with 63 subareas in total, see below), data was collected in written form. The questionnaires were hand-delivered into residential mail boxes. One person above 18 per household was asked to respond and return the survey. Each survey area contained 150 to 400 households (6620 in total).

In total, 1081 surveys were returned. The rate of participation of $16.24 \%$ is below response rates of similar surveys, which can be explained by the absence of a reminder due to a lack of recourses. The variation across the survey areas is high (response rates varied from $3.1 \%$ to $43.5 \%$ ). In general, the highest response rates were achieved in areas of people with a high socio-economic status and the lowest rates match those with a low socio-economic status ( $\mathrm{rho}=0.34$, significant at the 0.01 level).

The questions on noise annoyance could be answered on a four-level Likert scale, consisting of: very much, quite, somewhat and not at all (Table 1). 
Table 1. Variables from the survey used for analyses.

\begin{tabular}{|c|c|c|c|}
\hline Question & Variable & Answer scale & No. Cases (n) \\
\hline $\begin{array}{l}\text { Do you feel disturbed by noise in } \\
\text { your apartment/house? (noise of } \\
\text { every kind) }\end{array}$ & $\begin{array}{l}\text { NWD } \\
\text { NWE } \\
\text { NNI }\end{array}$ & $\begin{array}{l}\text { 4-level Likert (very much, } \\
\text { quite, some-what, not at all) }\end{array}$ & $\begin{array}{l}1036 \\
1020 \\
1022\end{array}$ \\
\hline $\begin{array}{l}\text { To what extent do you feel disturbed in your } \\
\text { apartment/house by road traffic noise? }\end{array}$ & NRT & $\begin{array}{l}\text { 4-level Likert (very much, } \\
\text { quite, some-what, not at all) }\end{array}$ & 1002 \\
\hline How old are you? & AGE & open & 1048 \\
\hline $\begin{array}{l}\text { What is the approximate monthly net income of your } \\
\text { household? (Combined disposable income of all } \\
\text { household members, incl. child support etc.) }\end{array}$ & INC & $\begin{array}{l}\text { Eleven classes in } 500 € \text { steps; } \\
\text { without limit from } 5000 € \text { up }\end{array}$ & 964 \\
\hline Highest level of education reached? & EDU & Five categories & 1057 \\
\hline $\begin{array}{l}\text { What is/are your occupation(s)? (Multiple answers } \\
\text { possible) }\end{array}$ & OCC & Seven categories, open answer & 1047 \\
\hline Gender? & GEN & Three categories (incl. other) & 1073 \\
\hline
\end{tabular}

Within the survey areas, the full sample of households was invited to participate. The urban blocks were selected based on four different parameters, some of which are not related to noise but were covered in the questionnaire due to the larger project context:

(1) Urban heat island (UHI) (based on Bechtel and Schmidt [69]) and modelled nighttime temperatures based on Boettcher et al. ([70])

(2) District types derived from urban morphology (based on Steward and Oke [71] and Kaveckis [72])

(3) Socio-economic status (SES) of the population (based on available statistical data of the city of Hamburg [73])

(4) Strategic noise map of the city of Hamburg [54]

The first three parameters are variables in the model of UrbWellth [21], linking this analysis closely to considerations of public health. Due to limited spatial public data, the socio-economic status was calculated for "statistical units" (834 for Hamburg, mean no. of residents $=2094$ ) based on the shares (a) of people receiving basic social security benefits; (b) unemployed adults; (c) children with a migrant background and living with single parents; (d) people older than 64 years (equally weighted). The final selection of survey areas was expert-driven and followed a matrix constructed from the parameters UHI, morphology and SES (same number of cases per class, Figure 1). The data of the strategic noise map was subsequently taken into account in the analysis (see below).

Additionally, the survey areas were supposed to roughly cover the city's spatial extend, which naturally resulted in differences in building types, ages and heights. An overview of relevant characteristics is presented in Table 2.

The final delineation of the survey areas was based on the buildings' locations in relation to roads and the data from the strategic noise map of the city of Hamburg [54]. Figure 2 shows survey area 6 as an example with three different subareas in a typical layout. These subareas are differentiated according to their traffic noise exposure by selecting residential buildings either facing a busy road ("Holländische Reihe", area 6a), facing side streets directly adjacent to the busy road (area 6b) or being separated from the busy road by at least one line of buildings (area 6c). Survey area 6 will be used consistently in the following sections to exemplify the results, while the results and conclusions are obviously based on an analysis of the full dataset.

Survey area 6 is located in an "Inner City" neighborhood. While subareas $6 \mathrm{a}$ and $6 \mathrm{~b}$ are mainly from the late 19th century/early 20th century, $6 \mathrm{c}$ represents a mixture from this era with newer buildings from the 1990s. The building height in the whole area is 5-6 stories. 


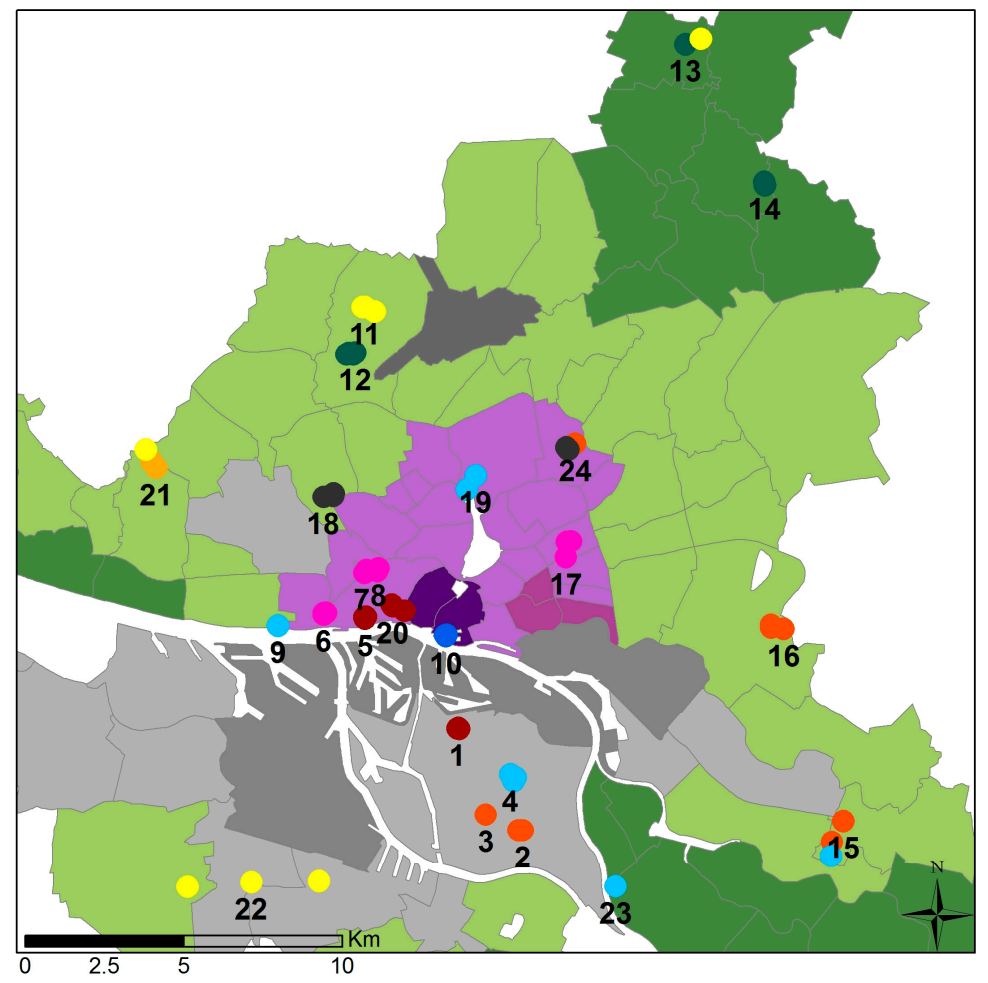

\section{Survey Areas}

1 - 24 No. of Survey Area

\section{Socio-economic Status and Urban Heat Island} low UHI Temp high

high

SES

low

\section{District Types}

- Old Town

Airport

Harbor, Business \& Industry

Inner City

Offices and Residential

- Suburban Areas

Harbor, Business \& Residential

$\square$ Transition Areas

Hintergrund

Figure 1. Distribution of survey areas over Hamburg (selection based on data of Steward and Oke [71], Kaveckis [72], Bechtel and Schmidt [69], Boettcher et al. [70], city of Hamburg [73]).

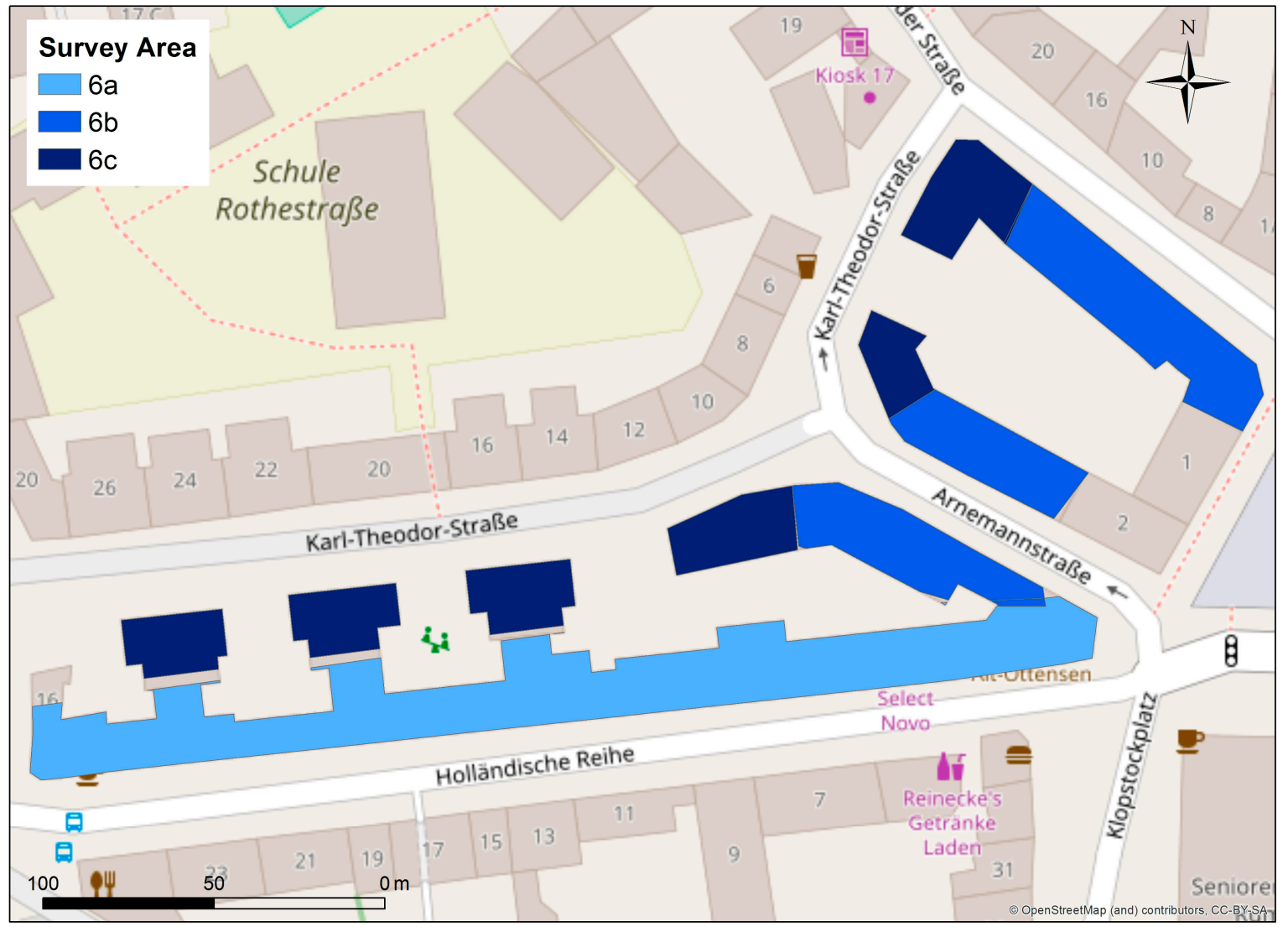

Figure 2. Subareas of survey area 6-typical layout of an inner-city survey area. 
Table 2. Overview of the survey areas: district, district type, and building types.

\begin{tabular}{|c|c|c|c|c|}
\hline $\begin{array}{l}\text { Survey } \\
\text { Area }\end{array}$ & District & District Type & Building Type & $\begin{array}{l}\text { No. of } \\
\text { Cases }(n)\end{array}$ \\
\hline 1 & Wilhelmsburg & Harbor, Business \& Residential & 1920s block building & 28 \\
\hline 2 & Wilhelmsburg & Harbor, Business \& Residential & 1970s large housing estate & 16 \\
\hline 3 & Wilhelmsburg & Harbor, Business \& Residential & 1950s apartment houses (rows) & 13 \\
\hline 4 & Wilhelmsburg & Harbor, Business \& Residential & 1950s row housing/town-houses/detached houses & 38 \\
\hline 5 & Altona-Altstadt & Inner City & 1920s block building & 26 \\
\hline 6 & Ottensen & Inner City & 1900s block building/Gap closing and re-compaction & 58 \\
\hline 7 & Altona-Nord & Inner City & 1950s-60s apartment houses/2010s block building & 42 \\
\hline 8 & Sternschanze & Inner City & 1900s block building & 55 \\
\hline 9 & Othmarschen & Transition Area & 1900s apartment \& detached houses & 24 \\
\hline 10 & Hafen City & Old Town & 2010s compact mid/high rise & 53 \\
\hline 11 & Niendorf & Transition Area & 1950s apartment houses (rows) /1970s high rise & 41 \\
\hline 12 & Niendorf & Transition Area & $\begin{array}{l}\text { 1980s/90s apartment houses/ } \\
\text { detached \& townhouses }\end{array}$ & 79 \\
\hline 13 & Duvenstedt & Suburban Area & 1900s-1990s apartment \& detached houses & 30 \\
\hline 14 & Bergstedt & Suburban Area & 1950s apartment houses (rows) & 19 \\
\hline 15 & Neuallermöhe & Transition Area & 1980s apartment houses & 69 \\
\hline 16 & Billstedt & Transition Area & 1960s apartment \& high rise & 33 \\
\hline 17 & Eilbek & Inner City & $\begin{array}{c}\text { 1960s apartment houses (gap closing)/1990s } \\
\text { apartment rows }\end{array}$ & 68 \\
\hline 18 & Eimsbüttel & Inner City & 1900s/1920s block buildings/mixed gap closings & 102 \\
\hline 19 & Winterhude & Inner City & 1900s large townhouses \& mixed apartment houses & 58 \\
\hline 20 & St. Pauli & Inner City & 1900s block building/Gap closing/2010s high rise & 60 \\
\hline 21 & Osdorf & Transition Area & 1970s large housing estate/ detached houses & 31 \\
\hline 22 & $\begin{array}{l}\text { Moorburg/ } \\
\text { Haus-bruch/ } \\
\text { Neugraben }\end{array}$ & $\begin{array}{l}\text { Transition Area/Harbor, } \\
\text { Business \& Residential }\end{array}$ & $\begin{array}{c}\text { 1920s-1980s apartment \& detached } \\
\text { houses/1990s block }\end{array}$ & 37 \\
\hline 23 & Ochsenwerder & Suburban Area & 1950s-1990s detached \& apartment houses & 24 \\
\hline 24 & Barmbek-Nord & Inner City & 1920s block building/1960s apartment houses & 77 \\
\hline
\end{tabular}

\subsection{Measuring and Modeling of Noise}

Both measured and modelled data were used to assess noise exposure. The first were collected for this study, the latter taken from the strategic noise map of the city of Hamburg [54]. Their exact determination and calculation are described in the following sections.

\subsubsection{Noise Measurements}

In order to obtain the highest possible accuracy, class 1 sound level meters from Cirrus (type CR:161B) were used, which comply with the standards and guidelines of Norm IEC 61672-1:2013. To capture the noise differences within each block, one sound level meter was placed on the roadside and another one to the off-road-side of the house. The sound level meters were placed at a distance of $1.5 \mathrm{~m}$ from the facade of the building and the microphones were adjusted at a height of $1.55 \mathrm{~m}$, complying with the guidelines ISO 1996-2:2017 [74].

In the context of this study, only noise levels during the day were examined. In order to guarantee comparability, all noise measurements were carried out between 4 p.m. and 7 p.m. on a Tuesday afternoon. This time period was chosen to include the heavy traffic loads during rush hour. Moreover, it can be assumed that a relevant proportion of the residents are already at home part of this time and thus affected by the noise observed.

In addition, several factors have an influence on the sound propagation. Generally, sound pressure levels decrease with the square of the distance to their source. By doubling the distance to the sound 
source, the sound level decreases by $6 \mathrm{~dB}(\mathrm{~A})$ in the case of point sources (single car) and by $3 \mathrm{~dB}(\mathrm{~A})$ in the case of line source (very busy road) [75], but attenuation due to ground effects and shielding has to be taken into account [76]. In addition, meteorological conditions influence sound propagation. For example, sound velocity and thus its range is dependent on ambient temperature with lower speed of sound at lower temperatures. The vertical temperature gradient also has a direct influence on sound propagation. If the ground air is cooler than above, sound travels faster but less far. The attenuation of sound also depends on humidity: with higher humidity, sound absorption in the air increases. Furthermore, both wind speed and turbulence have an influence on the sound pressure levels that arrive at receptor points $[75,77]$. Consequently, the metrological variables temperature, wind and precipitation were controlled during the measurement campaign to assure as comparable conditions as possible [74].

Overall, noise varies greatly over time. Therefore, the energy-equivalent continuous sound level $\left(L_{e q}\right)$ was calculated for comparison of the different survey areas. The $L_{e q}$ is based on the principle of energy equivalency, which assumes that the average sound energy of the variable noise profile over a period T has the same effect as a constant noise level of the same energy. The $L_{a e q}$ is the weighted $L_{e q}$ and is defined by the following formula:

$$
\begin{gathered}
L_{a e q}=10 \times \lg \left(\frac{1}{N} * \sum_{i=1}^{N} 10^{0.1 \times L_{i}}\right) \\
L_{a e q}=\text { Average noise level, } L_{i}=\text { dba depending on the time } t \text { and } \\
N=\text { Number of measured sound levels } L_{i}(1 \leq i \leq N)
\end{gathered}
$$

\subsubsection{Noise Map}

The latest road noise map was released in 2012 by the Behörde für Stadtentwicklung und Wohnen (BSW) [54]. It was created in accordance with the mandatory requirements for noise mapping specified in the European DIRECTIVE 2002/49/EC [78] (enacted into national law through the 34th German federal directive on emission protection, 34. BImSchV, [79]) using the software LimA 2.3. The modelling methodology specified in this directive is based on the French model "Nouvelle Méthode de Prévision de Bruit" (NMPB). Thus, the German methodology [79] is also based on this model.

The calculation of road traffic noise is based on the average number of vehicles per day, their maximum permissible speed and the proportion of heavy goods vehicles. The road's surface type and its slope are also taken into consideration. The calculation of the propagation of sound emissions takes into account artificial and natural obstacles as well as general meteorological conditions.

In correspondence with the standardized guidelines [78], road traffic noise immissions were calculated in decibels for a raster grid of $10 \mathrm{~m} \times 10 \mathrm{~m}$ at a height of $4 \mathrm{~m}$ above ground level. The unit used is decibel $(\mathrm{dB}(\mathrm{A}))$ - sound pressure scaled in accordance with the perceptual gradation of the human ear, which follows a logarithmic scale of sound pressure. The hearing threshold (set at $1000 \mathrm{~Hz}$ ) corresponds to $0 \mathrm{~dB}(\mathrm{~A})$, the pain threshold is known to be around about $130 \mathrm{~dB}(\mathrm{~A})$ [80].

DIRECTIVE 2002/49/EC demands calculation of the noise indices $L_{d e n}$ (day, evening and night) to assess annoyance, and $L_{\text {night }}$ to assess sleep disturbance [77]. $L_{\text {night }}$ is calculated as the average sound pressure equivalent for the hours between 22.00 and 6.00. The $L_{d e n}$ in $\mathrm{dB}(\mathrm{A})$ is defined by the following formula:

$$
L_{\text {den }}=10 \lg \frac{1}{24}\left(12 \times 10^{\frac{L_{\text {day }}}{10}}+4 \times 10^{\frac{L_{\text {evening }}+5}{10}}+8 \times 10^{\frac{L_{\text {night }}+10}{10}}\right)
$$

$L_{\text {day }}, L_{\text {evening }}$ and $L_{\text {night }}$ correspond to the A-weighted long-term average sound levels according to ISO 1996-2: 1987, determined over all the day periods, the evening periods and the night periods of a year respectively [78].

The output is a raster dataset. The dataset for Hamburg used in this study is available from Transparenzportal Hamburg [81]. The following figure (Figure 3) shows one of the research areas with the modelled noise data superimposed to exemplify the quality of the data available. 


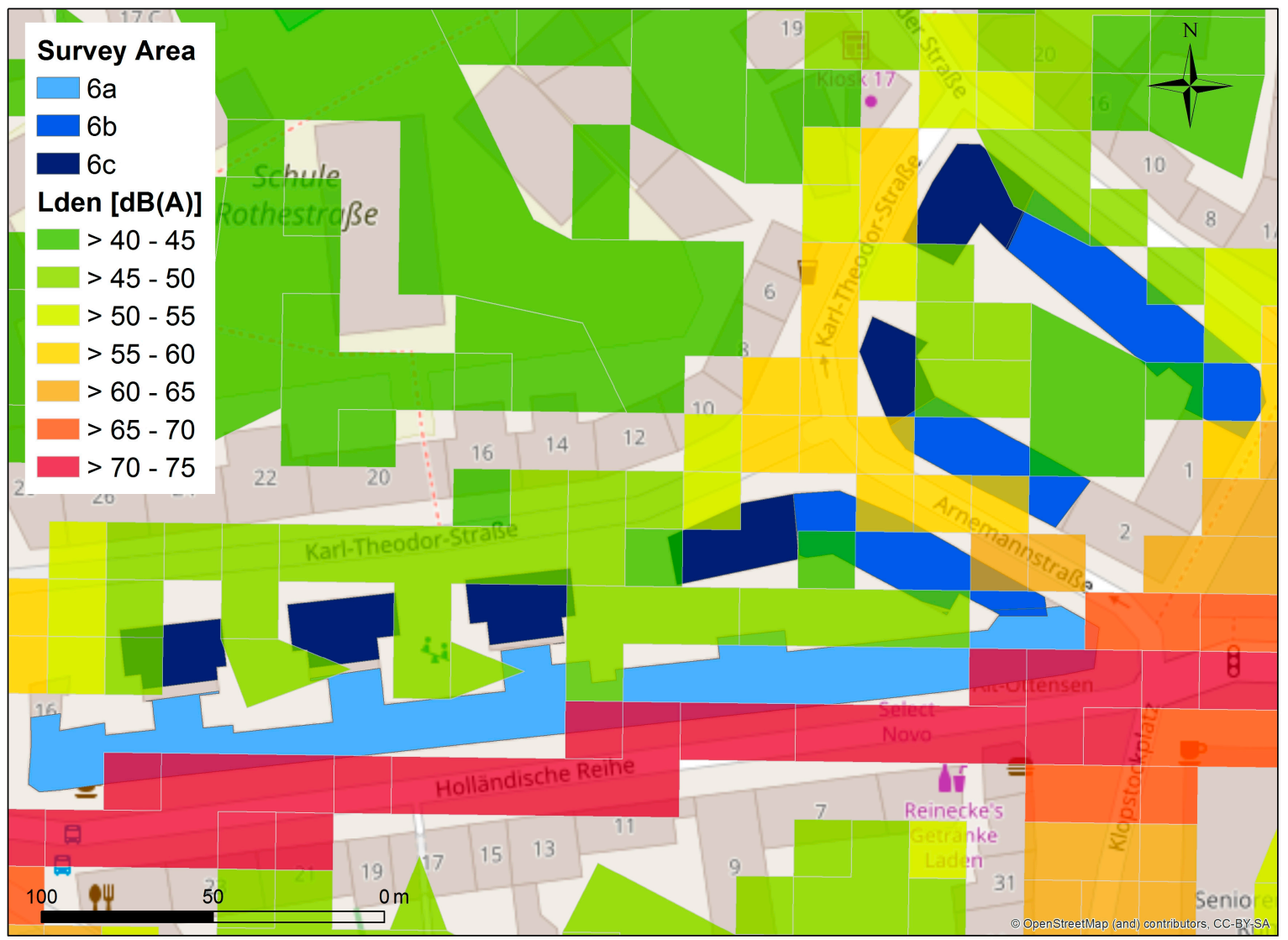

Figure 3. Traffic noise levels according to the noise map of Hamburg around survey area 6.

Since the noise map only provides a weighted energetic average of the sound levels over the $24 \mathrm{~h}$ day-evening-night period, the measurements should help to assess to what extent this corresponds to the actual ambient noise level on a midweek afternoon, but of course include not just traffic noise.

\subsection{Software Used and Modelling Approach}

\subsubsection{Statistical Analyses}

The survey data was collected on paper. For analyses, answers were entered into the package SPSS 24 (IBM) with the help of students. The 51 questions resulted in 152 variables as some questions comprised up to 12 variables. The average modelled noise levels for the survey areas resulting from the GIS analysis (see below) were integrated into this data set. In terms of socio-economic status, we selected age as horizontal and income as vertical stratification of the sample (see Table 1 and Section 3.3.2). Level of education was also investigated but did not result in significant correlations. We applied a bi-variate model to calculate correlations between the ordinal variables (Spearman's Rho in SPSS 24). Due to the simplicity of the model we did not adjust for confounding variables though we tested for the independence of the social variables (age and income do not correlate significantly).

Additional tests were necessary only for the analysis in Section 4.4 and the following statistical model was used: Analysis of variance (ANOVA) for age (metric variable) grouped by annoyance levels with a post hoc analysis according to Games-Howell; ANOVA tests for the difference in means of a metric variable (age) between more than two groups (annoyance levels reported). If ANOVA shows a significant difference, the Games-Howell procedure can be used to pinpoint which individual groups actually differ from each other. 


\subsubsection{Socio-Economic Analyses}

Based on the discussed literature, we selected the variables in Table 1. According to Dale et al. [33] and Mielck [82], income is considered to be the most important variable to illustrate the vertical stratification of urban society. It can also be assumed that income decisively shapes and pre-determines the possible choices of residential location in a city with a high-cost housing market like Hamburg's [83]. Based on the studies in Dortmund [34] and Oslo [84], age is the simplest approach to horizontal stratification. It was also found to have the biggest influence on noise annoyance (compared to other demographic factors) in some studies [85].

A socio-economic status index was calculated that took into account education and occupation (weighted equally with income). This approach was not pursued any further, however, since correlation of this SES index with the modeled noise data was weaker than the correlation of $L_{d e n}$ with income alone. In principle, it can be assumed that income decisively shapes and pre-determines the possible choices of residential location in a city like Hamburg.

A further complicating factor in this context is the missing assessment of migration background and the ineligibility of persons under the age of 18 in our dataset so that the SES index, which was calculated for the selection of study areas, could not be adequately reproduced. As participants were asked to fill out the questionnaire alone, a restriction to adults was necessary; migration background, however, is a complicated phenomenon in Germany, with very different countries of origin [86]. Therefore, we neither agree with the methodological decisions by Raddatz and Mennis to simply map overall migration background on neighborhood level [87] (primarily due to very different human development indexes of the countries of origin, compare Havard [36]), nor did we find appropriate means to measure something comparable to "ethnicity" ourselves (as commonly used in the US, for example). We actually discussed different ways of accessing migration background-and decided against it, because: (1) migration background was not the primary focus in one of our hypothesis; (2) due to the complexity of the topic it would have used up to $1 / 6$ of the questionnaire; (3) we saw a possible negative effect on the response rate of people with migration background (as questions regarding origin/ethnicity/race are always connoted politically in Germany). With growing evidence that complex indicators/factors for SES might not contribute to explain noise annoyance $[34,88]$ better, we decided for income and age only.

\subsubsection{Spatial Analyses}

For the spatial analysis of noise data as well as for all maps, the software ArcGIS (Version 10.3.1) was used. Besides the visualization of spatial data, ArcGIS provides functions to analyze existing patterns, the relationship between entities as well as spatial and temporal trends [89]. In particular, spatial analysis functions such as buffer and overlay were applied.

In the first step, a buffer was placed around the selected survey areas. Since noise data is not available for the grid cells which contain buildings [54] (see Figure 3) we applied a $3 \mathrm{~m}$ buffer to calculate the mean noise levels of the survey areas.

Subsequently, these enlarged polygons were combined with the noise map, assigning the arithmetic mean of the modeled noise in $L_{d e n}$ to the polygons (see Figure 4). The values were averaged for all subareas. This was done by calculating the arithmetic mean of all values for each geographic subarea within each study area.

As a result, we got $62\left(L_{d e n}\right)$ and $60\left(L_{\text {night }}\right)$ different average means of noise, which serve as expressions of our corresponding variables (Table 3 ). 


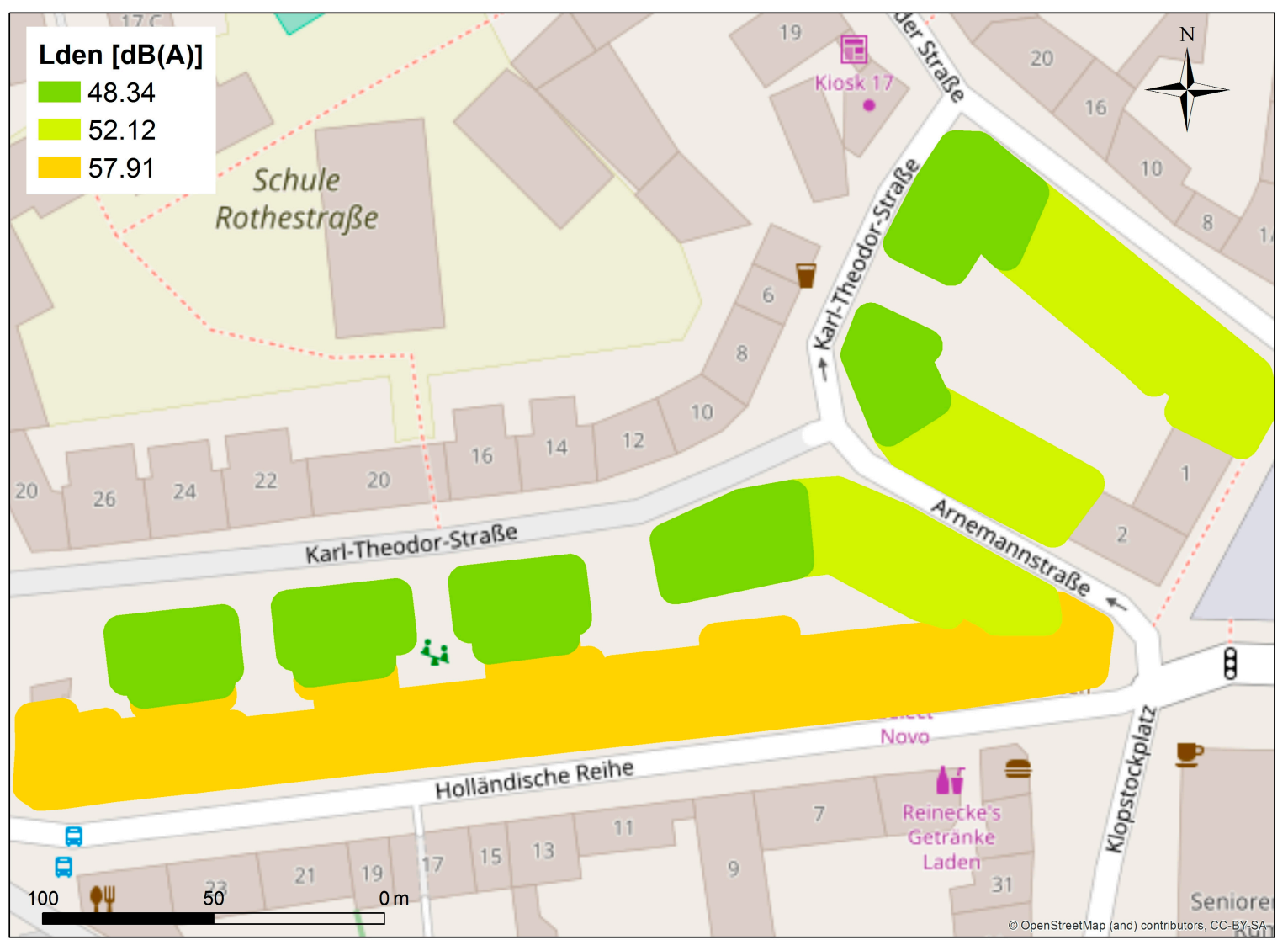

Figure 4. Mean noise levels with a $3 \mathrm{~m}$ buffer in survey area 6.

Table 3. Noise variables (data $L_{d e n}$ and $\left.L_{\text {night }}[53,54]\right)$.

\begin{tabular}{cccc}
\hline Variable & Source & Scale & No. of Cases \\
\hline$L_{\text {night }}$ & Strategic noise map, city of Hamburg & $\mathrm{dB}(\mathrm{A})$ & 60 different average means (for 1024 cases) \\
$L_{\text {den }}$ & Strategic noise map, city of Hamburg & $\mathrm{dB}(\mathrm{A})$ & 62 different average means (for 1057 cases) \\
$L_{\text {aeq }}$ & Measurements & $\mathrm{dB}(\mathrm{A})$ & 179 \\
\hline
\end{tabular}

\section{Results}

\subsection{Description of the Survey Sample}

Age and income are equally distributed over the different classes in this sample. The mean age is 52.4 years and therefore approximately 10 years above the average of Hamburg, mainly since the minimum age of the participants was 18 years. The median monthly net household income (estimated from relative frequencies and class means) of the sample (2250€) is very close to the median of Hamburg (2150€) (Figure 5) [90].

The sample is clearly biased towards female respondents ( $59 \%$ female) as well as respondents with a University degree (50\%, Figure 5). These biases correspond with the results of similar studies [91,92] and represent a self-selection effect of people prepared to participate in written surveys.

Overall, the sample is considered to provide a good representation of the research areas and also of the population of the city of Hamburg in total. 


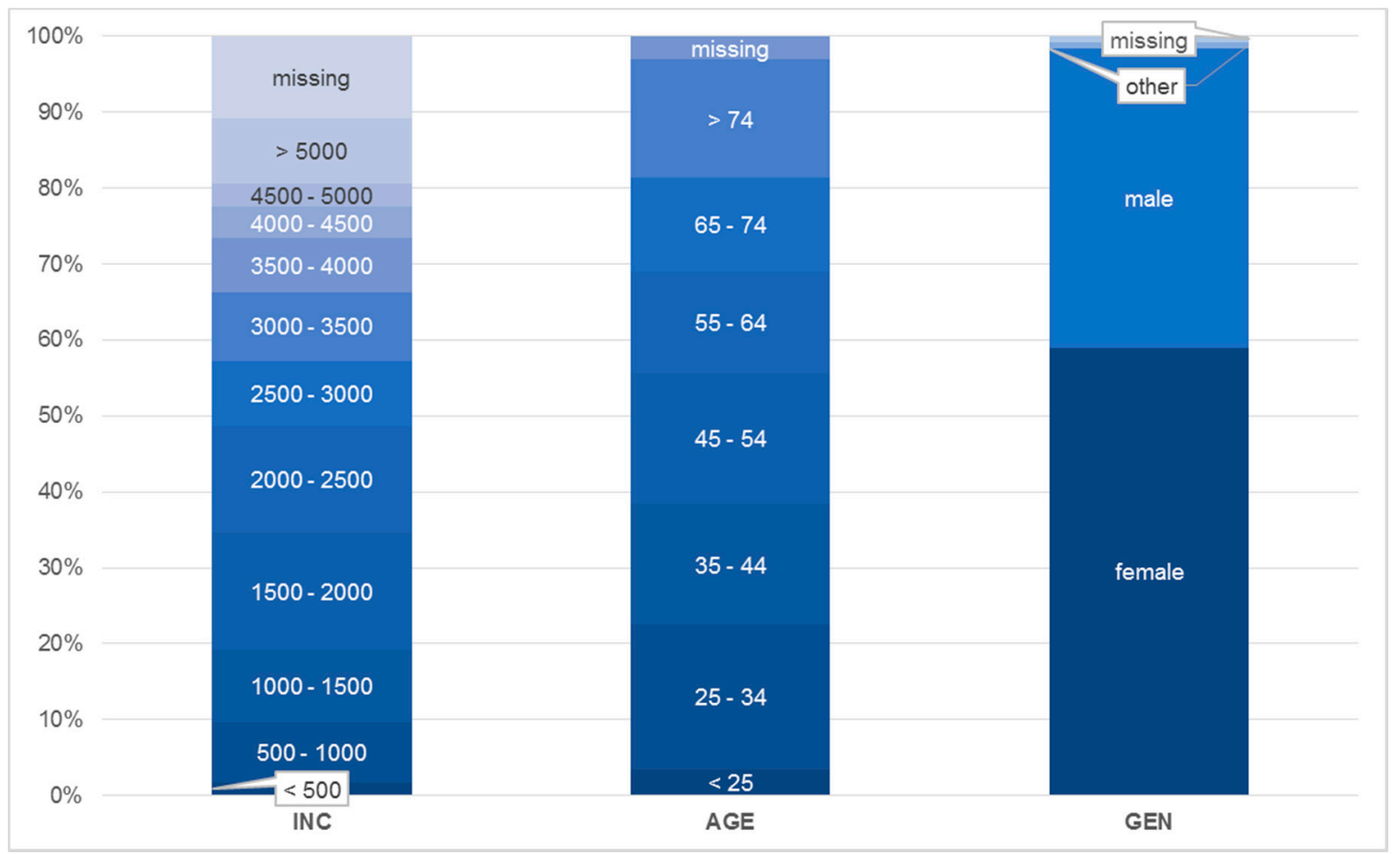

Figure 5. Distribution of income, educational classes and gender in the sample.

\subsection{Noise Pollution and Perception}

We found a moderate correlation between modelled exposure to noise and self-reported levels of annoyance by noise (Table 4). The relationships are highly significant for all variables of subjective rating of noise annoyance and they result in a small to medium effect size (as expressed by the coefficients). Unsurprisingly, the largest effect size is observed for the correlation between objective $L_{d e n}$ and subjective noise annoyance by traffic noise (NRT, last column). However, the importance of traffic noise for general noise annoyance is expressed by the highly significant correlations between $L_{d e n}$ and the overall subjective ratings of annoyance by noise $(p<0.001)$.

Table 4. Correlations of noise exposure $\left(L_{d e n}\right)$ and perception.

\begin{tabular}{|c|c|c|c|c|c|}
\hline & & \multicolumn{4}{|c|}{ Overall Annoyance by Noise } \\
\hline & & $\begin{array}{c}\text { Daytime Weekdays } \\
\text { (NWD) }\end{array}$ & $\begin{array}{c}\text { Daytime Weekends } \\
\text { (NWE) }\end{array}$ & Nights (NNI) & $\begin{array}{l}\text { Traffic Noise } \\
\text { (NRT) }\end{array}$ \\
\hline \multirow{2}{*}{$L_{d e n}$} & $r($ Spearman-Rho) & $0.23 * * *$ & $0.19 * * *$ & $0.23 * * *$ & $0.42^{* * *}$ \\
\hline & $d f$ & 1034 & 1018 & 1020 & 1000 \\
\hline
\end{tabular}

Figure 6 shows the results for survey area 6 . It can be seen that the subjective rating of traffic noise matches the expected noise burden calculated on the basis of the strategic noise map ( $L_{\text {den }}$, see above).

Therefore, the question "Is there a correlation between noise exposure and the subjective perception of this stressor?" can be answered in the affirmative. The strongest correlation is found between the calculated means of $L_{d e n}$ and NRT. This finding was robust even after consideration of additional variables to explain the perception of noise (see Section 4.4). 


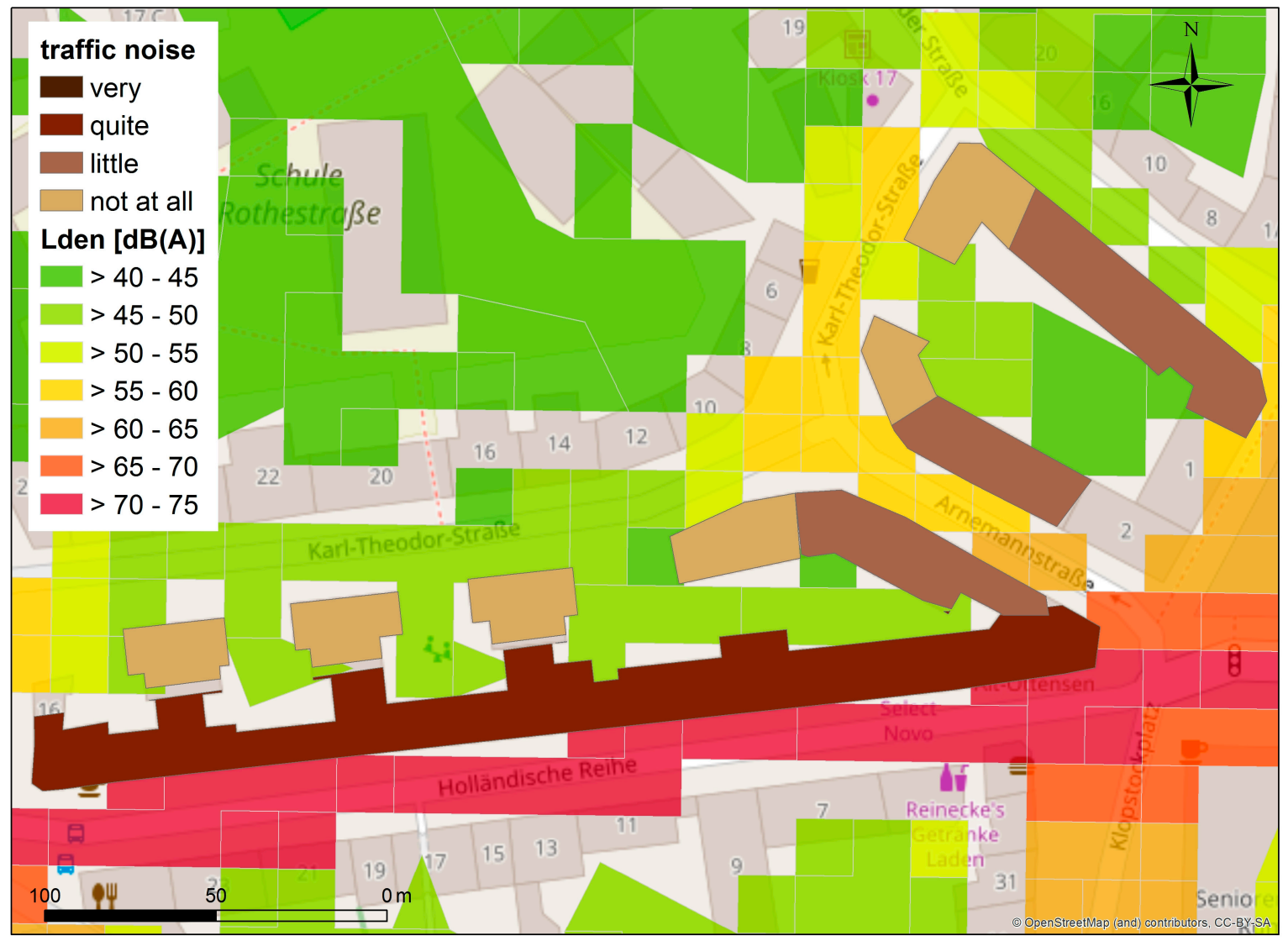

Figure 6. Subjective rating of annoyance by traffic noise in Subarea 6 data $L_{d e n}$ [54].

Additionally, the relations of measured noise and the perception of noise pollution were investigated. Although the sample size is much smaller $(n=179)$ since it was not measured at all survey sites, a similar relation between the perception and the measured $L_{a e q}$ was found. The correlation between $L_{a e q}$ and variables concerning noise during daytime (NWD, NEW) is almost identical to the modelled noise $\left(L_{d e n}\right)$ (Table 5).

Table 5. Correlations of noise exposure $\left(L_{a e q}\right)$ and perception.

\begin{tabular}{ccccc}
\hline & \multicolumn{3}{c}{ Overall Annoyance by Noise } \\
\cline { 2 - 5 } & & $\begin{array}{c}\text { Daytime Weekdays } \\
\text { (NWD) }\end{array}$ & $\begin{array}{c}\text { Daytime Week-Ends } \\
\text { (NWE) }\end{array}$ & $\begin{array}{c}\text { Traffic Noise } \\
\text { (NRT) }\end{array}$ \\
\hline \multirow{2}{*}{$L_{a e q}$} & $r($ Spearman-Rho) & $0.18^{*}$ & $0.19^{*}$ & $0.60 * * *$ \\
& $1 f$ & 177 & 175 & 174 \\
\hline \multicolumn{4}{c}{$p<0.05,{ }^{* * *} p<0.001}$.
\end{tabular}

Yet, the correlation for the $L_{a e q}$ class and traffic noise perception was found to be even stronger than for modelled noise and perception $\left(L_{d e n} r=0.42, L_{a e q} r=0.60\right.$; both $\left.p<0.001\right)$. Thus, we conclude that the measured data represent the average subjective burden of traffic noise better than modeled data. This is underpinned by an analysis of the distribution for each variable as presented in Figure 7 . Overall, for $L_{a e q}$ there is less variation in the data (extent of the boxes represents inter-quartile distance), especially for the categories "very much" and "quite" (annoyed by traffic noise). Additionally, median values of $L_{\text {aeq }}$ point to a higher level of noise pollution. This is not surprising, since measurements were primarily taken during peak hours. 


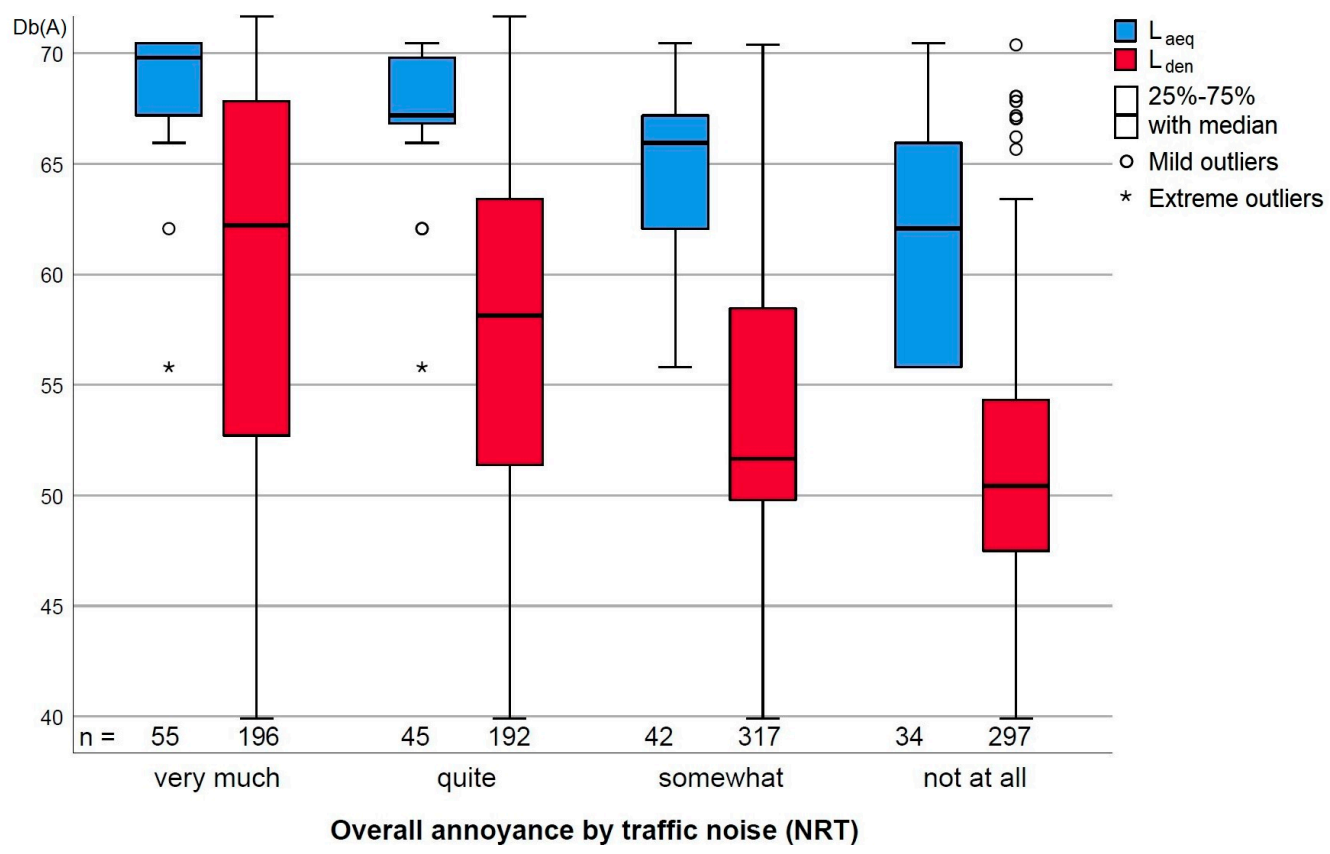

Figure 7. Distributions for $L_{d e n}$ and $L_{a e q}$ in relation to traffic noise NRT.

\subsection{Noise Pollution and Socio-Economic Parameters}

The spatial differences in pollution by noise and the small, block-level distribution of households in different income classes also show a correlation. Figure 8 visualizes the income distribution of survey area 6 .

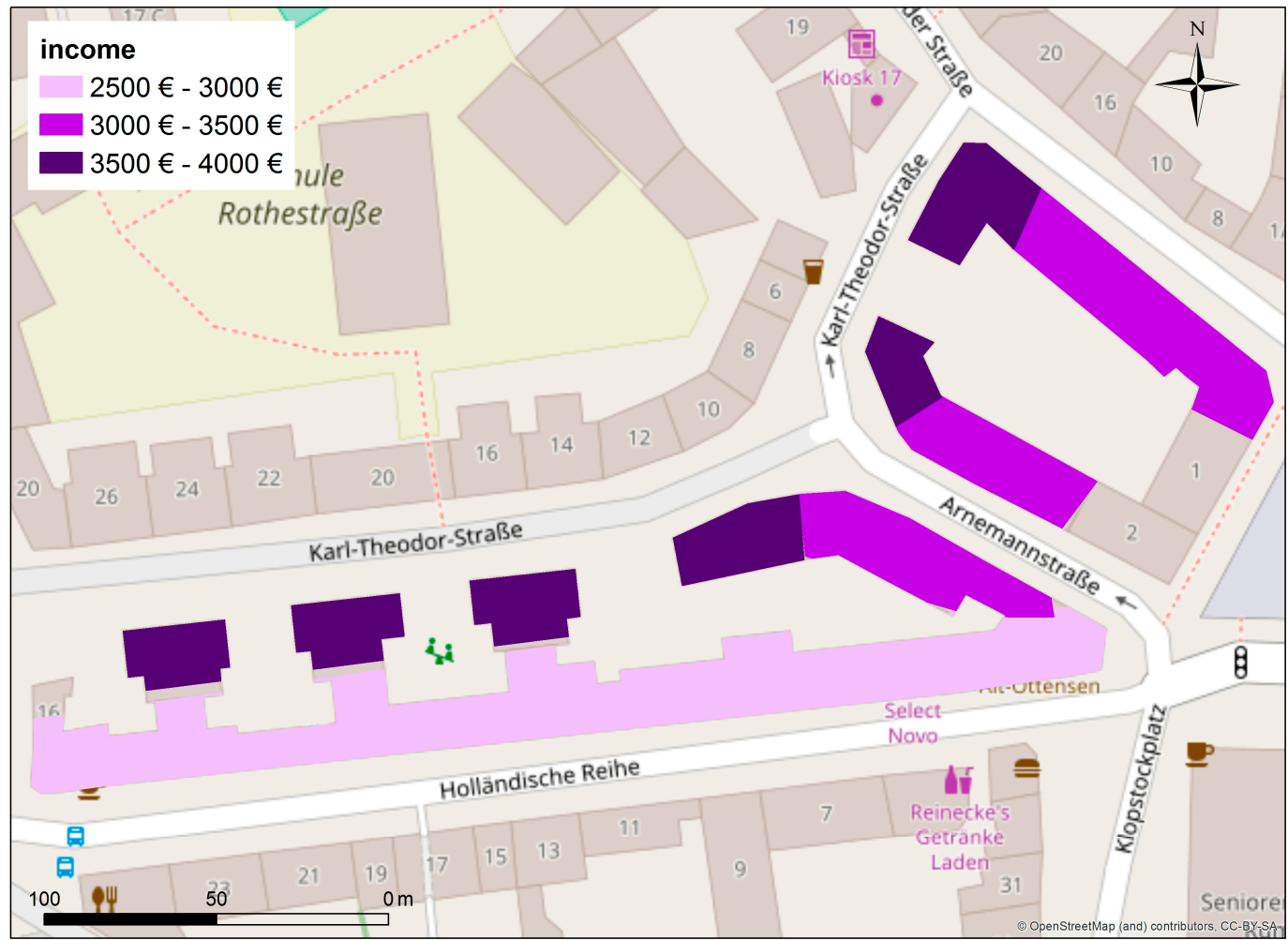

Figure 8. Mean income classes in subarea 6. 
With respect to the research question "Which socio-economic groups live mainly in noisy locations?" two highly significant bi-variate correlations were found for the entire sample. Firstly, the probability of living in a noisier area is higher for groups with a lower income $(r(941)=-0.17$, $p<0.001)$. Secondly, a significant correlation with age was found; the younger the participants, the more likely they live in a noisier location $(r(1023)=-0.21, p<0.001)$.

Figure 9 shows the distribution of the data for both variables. Interestingly, for income the greatest variation of income is given for the two most extreme $L_{d e n}$ classes. On the one hand, this can be attributed to attractive residential areas close to the city center with high noise pollution (e.g., parts of survey area 8 , see Figure 1), on the other hand, this can be explained by peripheral residential areas on the outskirts of the city, where problems are not primarily caused by traffic noise (e.g., parts of survey area 15). For both income and age, the medians show a clear correspondence to the correlation coefficients (see above).

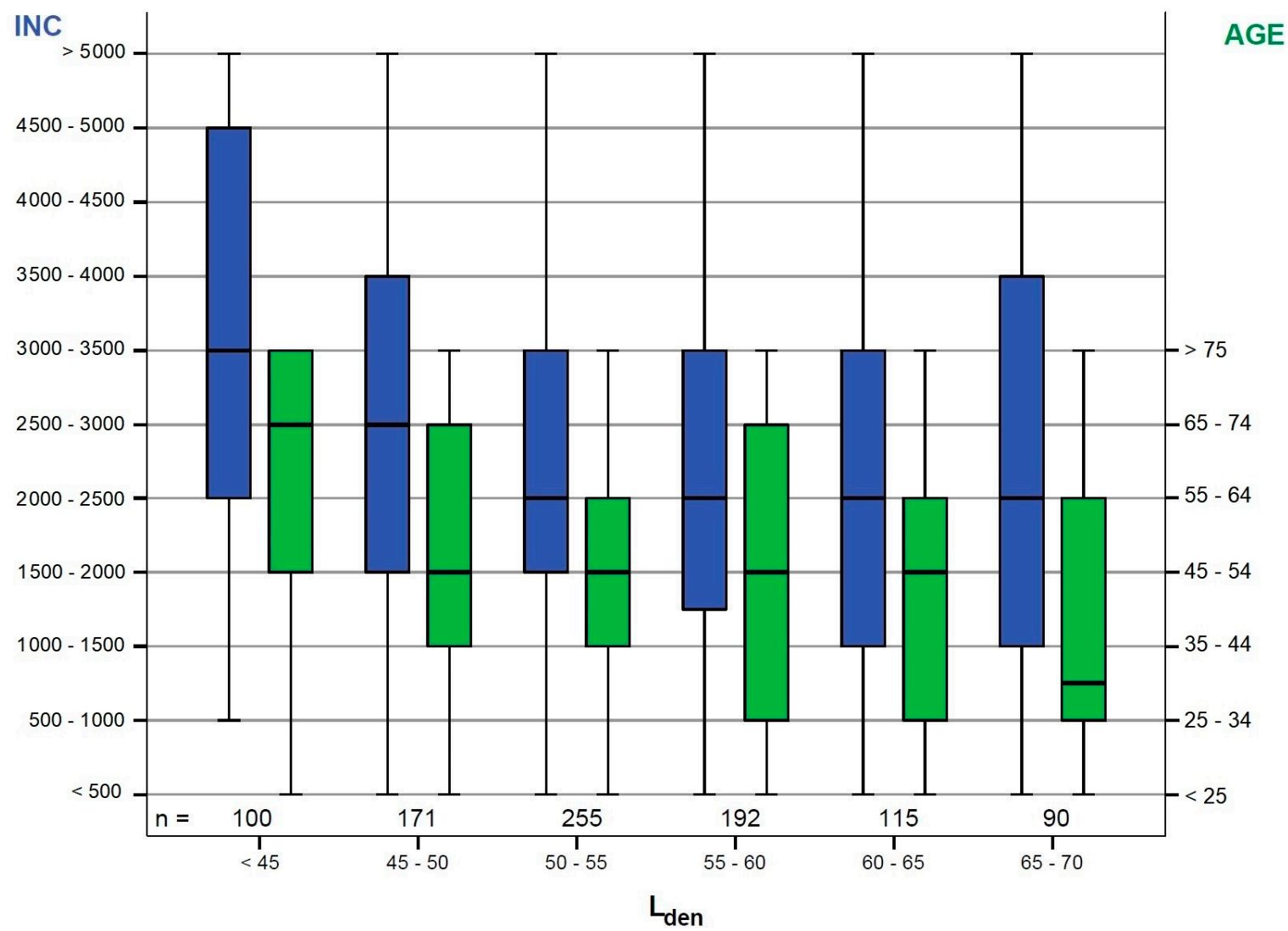

Figure 9. Distributions of income classes (in $€$ ) and age (10-year classes) for different noise exposure classes $\left(L_{d e n}\right.$ in $\left.\mathrm{dB}(\mathrm{A})\right)$.

\subsection{Noise Perception and Socio-Economic Parameters}

A significant overall correlation between age and the level of noise annoyance experienced at home was found for all noise parameters investigated (Table 6). Correlations between income and the subjective noise parameters were not significant.

Subsequently, the relationship between self-reported annoyance and age and level of education were analyzed. Therefore, the sample was subdivided into groups according to the $5 \mathrm{~dB}(\mathrm{~A})$ classes for $L_{d e n}$ and $L_{n i g h t}$ that are used for the strategic noise maps (see above). 
Table 6. Non-parametric correlations between age and reported annoyance by noise.

\begin{tabular}{cccccc}
\hline & & \multicolumn{3}{c}{ Overall Annoyance by Noise } \\
\cline { 2 - 5 } & & $\begin{array}{c}\text { Daytime Weekdays } \\
\text { (NWD) }\end{array}$ & $\begin{array}{c}\text { Daytime Weekends } \\
\text { (NWE) }\end{array}$ & Nights (NNI) & $\begin{array}{c}\text { Traffic Noise } \\
\text { (NRT) }\end{array}$ \\
\hline \multirow{2}{*}{ Age (years) } & $r$ (Spearman-ho) & $0.09^{* *}$ & $0.09^{* *}$ & $0.17^{* * *}$ & $0.16^{* * *}$ \\
& $1 f$ & 1025 & 1009 & 1011 & 991 \\
\hline
\end{tabular}

A significant relation between age and annoyance with night noise was found in the sub-sample experiencing road noise $L_{\text {night }}$ of $0-45 \mathrm{~dB}(\mathrm{~A})$. Of the respondents experiencing these modelled noise levels, those feeling not at all annoyed were significantly older than those feeling somewhat annoyed. There were also significant differences in mean ages for the self-reported levels of annoyance for people affected by both $L_{n i g h t}$ and $L_{d e n}$ of $>55-60 \mathrm{~dB}(\mathrm{~A})$, which is a moderate level for $L_{d e n}$ but quite high for nighttime exposure. These results are shown below in Table 7.

Table 7. Differences in mean age between groups reporting different levels of annoyance with road noise and night noise (from households exposed to $>55-60 \mathrm{~dB}(\mathrm{~A}) L_{d e n}$ and $L_{\text {night }}$ respectively).

\begin{tabular}{|c|c|c|}
\hline & $\mathrm{L}_{d e n}>55-60 \mathrm{~dB}(\mathrm{~A})$ & $\mathrm{L}_{\text {night }}>55-60 \mathrm{~dB}(\mathrm{~A})$ \\
\hline $\begin{array}{l}\text { Annoyance from } \\
\text { noise at night } \\
\text { (NNI) }\end{array}$ & $\begin{array}{l}>\text { very much } \bar{x}(45)=45 \text { years, } p<0.05 \text { vs. } \\
\text { somewhat } \bar{x}(62)=54.4 \text { years, } p<0.05\end{array}$ & $\begin{array}{l}>\text { very much } \bar{x}(56)=43.1 \text { years, } p<0.00 \text { vs. } \\
\text { somewhat } \bar{x}(41)=59 \text { years, } p<0.00 \\
>\text { very much } \bar{x}(56)=43.1 \text { years, } p<0.00 \text { vs. } \\
\text { not at all } \bar{x}(35)=54.7 \text { years, } p<0.00 \\
>\text { quite } \bar{x}(43)=46.9, p<0.00 \text { vs. } \\
\text { somewhat } \bar{x}(41)=59 \text { years, } p<0.00 \\
>\text { quite } \bar{x}(24)=40.2 \text { years, } p<0.00 \mathrm{vs} \text {. } \\
\text { not at all } \bar{x}(72)=58.5 \text { years, } p<0.00 \\
>\text { somewhat } \bar{x}(66)=46.7 \text { years, } p<0.00 \mathrm{vs.} \\
\text { not at all } \bar{x}(72)=58.5 \text { years, } p<0.00\end{array}$ \\
\hline
\end{tabular}

The results show that where there are significant differences in reported annoyance between people living within the same $5 \mathrm{~dB}(\mathrm{~A})$ noise bands, those reporting higher levels of annoyance from noise are, on average, younger than those feeling less annoyed. As we saw above, being younger also comes with a greater likelihood of in fact living in a noisier location (see Section 4.3). This might mean that people more sensitive to noise annoyance (due to their age) can be doubly affected by also experiencing higher noise exposure.

\section{Discussion, Conclusions and Outlook}

This study has investigated the distribution of noise pollution and its perception in urban blocks in Hamburg. Since the unequal distribution of stressors such as noise is commonly recognized as a first indicator of environmental injustice the guiding research questions will be discussed first. Secondly, our results will be reflected upon again in relation to EJ and future research possibilities will be identified.

First, for correspondences between exposure to noise and the level of perception (question 2), the micro-scale differences within building blocks of residential areas were found to be significantly correlated, both in terms of strong and moderate noise pollution (see Figures 4 and 6 above). It is important to note that the applied noise parameters used here as well as in planning describe outdoor noise near a building's facade. However, the noise levels experienced indoors can differ greatly depending on the sound insulation properties of walls and windows, the location of bedrooms and living rooms within a flat (facing towards the road or away from it) [32,34]. These factors obviously were not considered in our study. However, the measured values for $L_{a e q}$ explain 36 percent of the 
variance of the annoyance by traffic noise (NRT), and are thus a good and simple proxy for subjective noise annoyance.

Regarding the question who actually lives in the noisier areas (question 1), the research findings show that young(-er) people and people with low(-er) income are more likely to be exposed (Figure 9). The boxplot shows a small tendency for a U-shape for the connection of $L_{d e n}$ and income, which was related to the attractive city center locations in Hamburg. A similar, yet stronger U-connection was discovered for Marseille [37] and Amsterdam [93], showing the importance of context variables for the interpretation of results [36].

The results regarding the third question on the relationship between perception of traffic noise and social characteristics (such as age) revealed lower sensitivity to noise-annoyance for older people. This contrasts previous findings that people above 60 years do not respond differently to environmental noise [94]. Babisch et al. emphasize the importance of the subjective assessment of noise pollution by those affected $[95,96]$. Therefore, we argue that the health effect of noise is not independent of the rating on subjective annoyance [83,97]. This raises the questions if habituation [21] (due to a long period of residence) or declining hearing capacity with increasing age could have a positive effect on noise annoyance and thus also on other health outcomes (such as hypertension). However, results of Riedel et al. suggest that self-reported hearing disability enhanced noise annoyance [34]. As only little variance is explained in both studies, further research on this topic is needed. This might also help to clarify the overall suitability of age as an indicator for noise vulnerability [88].

Overall, these results show that despite management of environmental noise in accordance with EU regulations and legal noise limits for urban areas substantial disturbance by environmental noise remains in residential populations. Furthermore, noise is modelled for highly trafficked streets only [78], leaving numerous residential areas out of the picture [34]. Consequently, noise and EJ became central topics in the German debate about urban restructuring recently, especially in Hamburg [98,99].

The results presented in this paper give evidence for some assumptions derived from previous research [1-6]: it is indeed mostly people with a low(er) SES and young(er) people who live in noisy locations. As these findings refer back to the conceptual considerations on EJ, it still has to be proven that this situation is environmentally unjust. We argued that normative aspects of EJ, e.g., including power relations (in the sense of (in-)equality of opportunities, for example) have to be considered [15-17]. Therefore, the individual perception of noise as an environmental stressor has been included in this case study. However, to prove the injustice of the situation not only in terms of distribution but also in terms of (in)just processes, future research has to take into account more context data. Privatization of public housing has a driving effect on rents [100], for example, leading to an increase of prices for accommodation in general [101] and in the long term to a situation in which large parts of the population hardly have a choice of housing in case of (necessary) moves [102].

Therefore, if we apply the assumption of Davoudi and Atkinson of a decline in attempts by planners to reduce spatial inequalities and social segregation since the 1980s [102,103] to Hamburg, the results of this paper indicate indeed distributional and procedural environmental injustice [104]. However, sensitivities and adaptive capacities of the different populations need to be considered further [105] as residents' vulnerability might increase. Unfortunately, this points to a flaw of our dataset since the overrepresentation of higher-educated people might be considered to be a representation of environmental injustice, too. Those who have less adaptive capacities to cope with noise report less in surveys and are likely to have less power in political decision-making procedures that intend to evaluate or reduce environmental burdens.

Yet, living in a potentially calmer, peripheral—and possibly also cheaper-district not only leads to questions of participation but to an equal "right to the city" [106] in general, including a right to public transportation [107] to still be able to participate in every-day life of the city society. With all these different approaches and dimensions of justice, we support Walker's claim "that outside the realms of abstract conceptual debate, separating out the multiple dimensions of justice and environment may both be futile and of only limited value" [108]. 
Returning thus to the more abstract level of the relationship between equality and justice with respect to exposure to environmental stressors and going beyond descriptions related to age and income, future research is needed (a) including more social and cultural characteristics (and vulnerabilities) of urban citizens in heterogeneous societies and (b) regarding normative questions of socio-spatial inequality and injustice. As Preisendörfer has argued, justice is not equity and vice versa, because distributional justice can be read differently: For example, does the objective of distributional justice of noise emissions rely on equal distribution of the emissions to all urban blocks and districts or does it rather stand for a reduction of the existent emissions in particularly affected parts of the city to the average level (thus maybe creating another level of inequality) [19]?

One answer could be the reduction of noise emission from road traffic through a general speed limit. Emissions of road traffic noise depend mostly on the following factors: traffic volume, speed and flow (free-flowing vs. accelerating as at junctions), and the share of heavy goods vehicles. Doubling traffic volumes results in an average increase of $3 \mathrm{~dB}(\mathrm{~A})$ in emissions, while sound pressure levels generally double when the traffic volume increases tenfold. Depending on fleet composition, a speed reduction from about $60 \mathrm{~km} / \mathrm{h}$ to $30 \mathrm{~km} / \mathrm{h}$ achieves an emission reduction of 3-4 dB(A) in free-flowing traffic while at comparable speeds, a heavy goods vehicle emits the same level of sound as up to 30 cars [109]. For cars and vans, the tire-on-road noise tends to dominate sound emissions upward of about $30 \mathrm{~km} / \mathrm{h}$. while in heavy duty vehicles, engine noise generally dominates in urban traffic conditions [110]. Therefore, a general speed limit at $30 \mathrm{~km} / \mathrm{h}$ could have a substantial effect on the noise pollution in Hamburg.

There are substantial normative approaches that link the unequal distribution of environmental stressors to social justice in the sense of 'a right to health' for everybody [111]. Stephens, for example, sheds light on the difference between urban inequality and inequity-the first being reduced to different conditions, the latter referring to injustice due to power relations, policy processes and socioeconomic structures that influence where people live and why [112]. Moreover, since urban citizens are affected differently by the same stressor-as this research on noise has identified (see Reckien et al. and Sicotte for various other stressors $[113,114]$ ) — the objective of EJ needs to be addressed in terms of inequity, rather than inequality in future research and in political action: "where particular impacts on vulnerable or disadvantaged communities are identified, mitigation measures might also be developed and negotiated in order to try and address the imbalance in benefits and burdens that are involved" [115].

Despite these normative questions, more empirical research on the actual relation between exposure, perception and health effects of relevant environmental stressors at different scales is needed. Focusing on road traffic noise exposure and perception in a small-scale residential area, this study added empirical evidence to the annoyance from road traffic at urban block scale and thereby moreover outlined a methodological approach which enables a more substantive investigation of EJ by taking into account subjective and objective measures of exposure on a small local scale.

Acknowledgments: This contribution is based on the work of the research project "Cities in ChangeDevelopment of a multi-sectoral urban-development impact model (UrbMod)", a joint project of University of Hamburg, Hamburg University of Technology, University Medical Center Hamburg-Eppendorf, Institute of Coastal Research at Helmholtz Center Geesthacht, Max-Planck-Institute for Meteorology, and Hafen-City University, funded by the State of Hamburg. Part of this work is supported through the Cluster of Excellence "Integrated Climate System Analysis and Prediction" (CliSAP) (EXC177), University of Hamburg, funded through the German Science Foundation (DFG). For support with the questionnaire we thank Christian Schuster, Jasmin Honold, Thomas Pohl, Michael Krey, Maximilian Freude, Lena Bernhardi and Torben Kraft.

Author Contributions: Malte von Szombathely was responsible for the conception, completion of the survey, the data analysis and the draft manuscript. All co-authors provided input and comments on the manuscript.

Conflicts of Interest: The authors declare no conflict of interest. The founding sponsors had no role in the design of the study; in the collection, analyses, or interpretation of data; in the writing of the manuscript, and in the decision to publish the results. 


\section{References}

1. Pulido, L. Flint, Environmental Racism, and Racial Capitalism. Capital. Nat. Social. 2016, 27, 1-16. [CrossRef]

2. Erhart, M.; Hering, R.; Schulz, M.; Graf von Stillfried, D. Morbiditaetsatlas Hamburg: Gutachten zum KleinräUmigen Versorgungsbedarf in Hamburg; Erstellt Durch das Zentralinstitut für die KassenäRztliche Versorgungin Deutschland im Auftrag der Behörde für Gesundheit und Verbraucherschutz Hamburg: Hamburg, Germany, 2013.

3. Wing, S. Science for Reducing Health Inequalities Emerges from Social Justice Movements. New Solut. 2016, 26, 103-114. [CrossRef] [PubMed]

4. Bullard, R.D. Unequal Protection. Environmental Justice and Communities of Color; Sierra Club Books: San Francisco, CA, USA, 1994.

5. James, W.; Jia, C.; Kedia, S. Uneven magnitude of disparities in cancer risks from air toxics. Int. J. Environ. Res. Public Health 2012, 9, 4365-4385. [CrossRef] [PubMed]

6. Bullard, R.D. Solid Waste Sites and the Black Houston Community. Sociol. Inq. 1983, 53, 273-288. [CrossRef] [PubMed]

7. Maschewsky, W. Umweltgerechtigkeit, Public Health und Soziale Stadt; VAS Verlag für Akademische Schriften: Frankfurt, Germany, 2001.

8. Maschewsky, W. Umweltgerechtigkeit. Gesundheitsrelevanz und Empirische Erfassung; Wissenschaftszentrum Berlin für Sozialforschung (WZB): Berlin, Germany, 2004.

9. Umweltbundesamt. Umweltgerechtigkeit-Umwelt, Gesundheit und Soziale Lage. Available online: https:/ / www.umweltbundesamt.de/themen/gesundheit/umwelteinfluesse-auf-den-menschen/ umweltgerechtigkeit-umwelt-gesundheit-soziale-lage (accessed on 23 January 2018).

10. Evans, G.W. The built environment and mental health. J. Urban Health Bull. N. Y. Acad. Med. 2003, 80, 536-555. [CrossRef] [PubMed]

11. Lee, C. Environmental justice: Building a unified vision of health and the environment. Environ. Health Perspect. 2002, 110, 141-144. [CrossRef] [PubMed]

12. Brulle, R.J.; Pellow, D.N. Environmental justice: Human health and environmental inequalities. Annu. Rev. Public Health 2006, 27, 103-124. [CrossRef] [PubMed]

13. Taylor, W.C.; Floyd, M.F.; Whitt-Glover, M.C.; Brooks, J. Environmental justice: A framework for collaboration between the public health and parks and recreation fields to study disparities in physical activity. J. Phys. Act. Health 2007, 4, 50-63. [CrossRef]

14. Bolte, G.; Mielck, A. Die soziale Verteilung von Umweltbelastungen: Neue Impulse für Public Health Forschung und Praxis. In Umweltgerechtigkeit: Die Soziale Verteilung von Umweltbelastungen; Bolte, G., Ed.; Juventa: Weinheim, München, 2004; pp. 7-28.

15. Walker, G.P. Environmental Justice. Concepts, Evidence and Politics; Routledge: London, UK, 2012.

16. Holifield, R. Environmental justice and political ecology. In The Routledge Handbook of Political Ecology, 1st ed.; Perreault, T., Bridge, G., McCarthy, J., Eds.; Routledge: London, UK, 2015; pp. 585-597.

17. Young, I.M. Justice and the Politics of Difference; Paperback Reissue [Electronic Version]; Princeton University Press: Princeton, NJ, USA, 2011.

18. Bolte, G.; Bunge, C.; Hornberg, C.; Köckler, H.; Mielck, A. (Eds.) Umweltgerechtigkeit. Chancengleichheit bei Umwelt und Gesundheit: Konzepte, Datenlage und Handlungsperspektiven, 1st ed.; Verlag H. Huber: Bern, Switzerland, 2012.

19. Preisendörfer, P. Umweltgerechtigkeit: Von sozial-räumlicher Ungleichheit hin zu postulierter Ungerechtigkeit lokaler Umweltbelastungen. Soziale Welt 2014, 65, 25-45. [CrossRef]

20. Kohlhuber, M.; Mielck, A.; Weiland, S.K.; Bolte, G. Social inequality in perceived environmental exposures in relation to housing conditions in Germany. Environ. Res. 2006, 101, 246-255. [CrossRef] [PubMed]

21. Von Szombathely, M.; Albrecht, M.; Antanaskovic, D.; Augustin, J.; Augustin, M.; Bechtel, B.; Bürk, T.; Fischereit, J.; Grawe, D.; Hoffmann, P.; et al. A Conceptual Modeling Approach to Health-Related Urban Well-Being. Urban Sci. 2017, 1, 17. [CrossRef]

22. Babisch, W.; Wolf, K.; Petz, M.; Heinrich, J.; Cyrys, J.; Peters, A. Associations between Traffic Noise, Particulate Air Pollution, Hypertension, and Isolated Systolic Hypertension in Adults: The KORA Study. Environ. Health Perspect. 2014, 122, 492-498. [CrossRef] [PubMed] 
23. Van Kempen, E.; Babisch, W. The quantitative relationship between road traffic noise and hypertension. J. Hypertens. 2012, 30, 1075-1086. [CrossRef] [PubMed]

24. Ising, H.; Babisch, W.; Kruppa, B. Noise-induced endocrine effects and cardiovascular risk. Noise Health 1999, 1,37-48. [PubMed]

25. Bockelbrink, A.; Willich, S.N.; Dirzus, I.; Reich, A.; Lau, S.; Wahn, U.; Keil, T. Environmental Noise and Asthma in Children: Sex-Specific Differences. J. Asthma 2008, 45, 770-773. [CrossRef] [PubMed]

26. Duhme, H.; Weiland, S.K.; Keil, U.; Kraemer, B.; Schmid, M.; Stender, M.; et al. The association between self-reported symptoms of asthma and allergic rhinitis and self-reported traffic density on street of residence in adolescents. Epidemiology 1996, 7, 578-582. [CrossRef] [PubMed]

27. Ising, H.; Lange-Asschenfeldt, H.; Lieber, G.F.; Weinhold, H.; Eilts, M. Effects of long-term exposure to street traffic exhaust on the development of skin and respiratory tract diseases in children. Schriftenr. Ver. Wasser Boden Lufthyg. 2003, 112, 81-99.

28. Casey, J.A.; Morello-Frosch, R.; Mennitt, D.J.; Fristrup, K.; Ogburn, E.L.; James, P. Race/ethnicity, socioeconomic status, residential segregation, and spatial variation in noise exposure in the contiguous United States. Environ. Health Perspect. 2017, 125, 077017. [CrossRef] [PubMed]

29. Federal Republic of Germany. Sechste Allgemeine Verwaltungsvorschrift zum Bundes-Immissionsschutzgesetz (Technische Anleitung zum Schutz Gegen Lärm-TA Lärm); TA Lärm; Federal Republic of Germany: Bonn, Germany, 1998.

30. Federal Republic of Germany. Sechzehnte Verordnung zur Durchführung des Bundes-Immissionsschutzgesetzes (Verkehrslärmschutzverordnung - 16. BImSchV); 16. BImSchV; Federal Republic of Germany: Bonn, Germany, 1990.

31. Carrier, M.; Apparicio, P.; Seguin, A.M. Road traffic noise in Montreal and environmental equity: What is the situation for the most vulnerable population groups? J. Transp. Geogr. 2016, 51, 1-8. [CrossRef]

32. Becker, T. Sozialräumliche Verteilung von Verkehrsbedingtem Lärm und Luftschadstoffen am Beispiel von Berlin; Technische Universität Dresden: Dresden, Germany, 2016.

33. Dale, L.M.; Goudreau, S.; Perron, S.; Ragettli, M.S.; Hatzopoulou, M.; Smargiassi, A. Socioeconomic status and environmental noise exposure in Montreal, Canada. BMC Public Health 2015, 15, 1-8. [CrossRef] [PubMed]

34. Riedel, N.; Scheiner, J.; Müller, G.; Köckler, H. Assessing the relationship between objective and subjective indicators of residential exposure to road traffic noise in the context of environmental justice. J. Environ. Plan. Manag. 2014, 57, 1398-1421. [CrossRef]

35. Lakes, T.; Brückner, M. Socio-spatial Distribution of Noise Exposure in Berlin. In Environmental Justice, II. Special Issue; Federal Environmental Agency: Berlin, Germany, 2011.

36. Havard, S.; Reich, B.J.; Bean, K.; Chaix, B. Social inequalities in residential exposure to road traffic noise: An environmental justice analysis based on the RECORD Cohort Study. Occup. Environ. Med. 2011, 68, 366-374. [CrossRef] [PubMed]

37. Bocquier, A.; Cortaredona, S.; Boutin, C.; David, A.; Bigot, A.; Chaix, B.; Gaudart, J.; Verger, P. Small-area analysis of social inequalities in residential exposure to road traffic noise in Marseille, France. Eur. J. Public Health 2012, 23, 540-546. [CrossRef] [PubMed]

38. Schweitzer, L.; Valenzuela, A. Environmental injustice and transportation: The claims and the evidence. J. Plan. Lit. 2004, 18, 383-398. [CrossRef]

39. Senatsverwaltung für Stadtentwicklung und Wohnen. Umweltatlas Berlin. Available online: http:/ / www. stadtentwicklung.berlin.de/umwelt/umweltatlas/index.shtml (accessed on 23 January 2018).

40. Lakes, T.; Brückner, M.; Krämer, A. Development of an environmental justice index to determine socioeconomic disparities of noise pollution and green space in residential areas in Berlin. J. Environ. Plan. Manag. 2014, 57, 538-556. [CrossRef]

41. Flacke, J.; Schüle, S.A.; Köckler, H.; Bolte, G. Mapping Environmental Inequalities Relevant for Health for Informing Urban Planning Interventions: A Case Study in the City of Dortmund, Germany. Int. J. Environ. Res. Public Health 2016, 13, 711. [CrossRef] [PubMed]

42. Cesaroni, G.; Badaloni, C.; Romano, V.; Donato, E.; Perucci, C.A.; Forastiere, F. Socioeconomic position and health status of people who live near busy roads: The Rome Longitudinal Study (RoLS). Environ. Health 2010, 41, 1-12. [CrossRef] [PubMed] 
43. Kohlhuber, M.; Heinrich, J.; Van Den Hazel, P.; Zuurbier, M.; Bistrup, M.L.; Koppe, J.G.; Bolte, G. Children's environmental health: Why should social disparities be considered? Acta Pxdiatrica 2016, 95, 26-30. [CrossRef] [PubMed]

44. Oiamo, T.H.; Davies, H.; Rinner, C. Environmental Noise Study in the City of Toronto; City of Toronto Public Health Project: Toronto, ON, Canada, 2017.

45. Nega, T.H.; Chihara, L.; Smith, K.; Jayaraman, M. Traffic noise and inequality in the twin cities, Minnesota. Hum. Ecol. Risk Assess. Int. J. 2013, 19, 601-619. [CrossRef]

46. Lam, K.-C.; Chan, P.-K. Socio-economic status and inequalities in exposure to transportation noise in Hong Kong. Transportation 2006, 2, 107-113. [CrossRef]

47. Moreno-Jiménez, A.; Cañada-Torrecilla, R.; Vidal-Domínguez, M.J.; Palacios-García, A.; Martínez-Suárez, P. Assessing environmental justice through potential exposure to air pollution: A socio-spatial analysis in Madrid and Barcelona, Spain. Geoforum 2016, 69, 117-131. [CrossRef]

48. Bowen, W. An Analytical Review of Environmental Justice Research: What Do We Really Know? Environ. Manag. 2002, 29, 3-15. [CrossRef]

49. Brender, J.D.; Maantay, J.A.; Chakraborty, J. Residential Proximity to Environmental Hazards and Adverse Health Outcomes. Am. J. Public Health 2011, 101, S37-S52. [CrossRef] [PubMed]

50. Mennis, J. Using geographic information systems to create and analyze statistical surfaces of population and risk for environmental justice analysis. Soc. Sci. Q. 2002, 83, 281-297. [CrossRef]

51. Schweitzer, L.A.; Stephenson, M., Jr. Right Answers, Wrong Questions: Environmental Justice as Urban Research. Urban Stud. 2007, 44, 319-337. [CrossRef]

52. Tobler, W.R. A Computer Movie Simulating Urban Growth in the Detroit Region. Econ. Geogr. 1970, 46, 234-240. [CrossRef]

53. BSU—Behörde für Stadtentwicklung und Umwelt. Strategische Lärmkarte Straßenverkehr Lnight. Available online: http:/ / www.hamburg.de/contentblob/3476532/data/lnight-strasse-2012.pdf (accessed on 23 January 2018).

54. BSU—Behörde für Stadtentwicklung und Umwelt. Strategische Lärmkarte Straßenverkehr Lden. Available online: http:/ / www.hamburg.de/contentblob/3476512/data/lden-strasse-2012.pdf (accessed on 23 January 2018).

55. Bolte, G.; Kohlhuber, M. Untersuchungen zur Ökologischen Gerechtigkeit: Explorative Vorbereitungsstudie. Teilprojekt A: Systematische Zusammenstellung der Datenlage in Deutschland; Umweltforschungsplan 3707 17 102/01; Umweltbundesamt (UBA): Dessau-Roßlau, Germany, 2008.

56. Hornberg, C.; Bunge, C.; Pauli, A. Strategien für Mehr Umweltgerechtigkeit. Handlungsfelder für Forschung und Praxis; Universität Bielefeld: Bielefeld, Germany, 2011.

57. Bunge, C. Umweltgerechtigkeit. Soziale und Räumliche Verteilung Gesundheitsrelevanter Umweltbelastungen und -Ressourcen; Verlang H. Huber: Bern, Germany, 2013.

58. Köckler, H. Umweltbezogene Gerechtigkeit und Immissionsbelastungen am Beispiel der Stadt Kassel; Kassel Univ. Press: Kassel, Germany, 2008.

59. Baranzini, A.; Schaerer, C.; Thalmann, P. Using measured instead of perceived noise in hedonic models. Transp. Res. Part D Transp. Environ. 2010, 15, 473-482. [CrossRef]

60. Gaffron, P. Urban transport, environmental justice and human daily activity patterns. Trans. Policy 2012, 20, 114-127. [CrossRef]

61. Balestroni, G.; Bertolotti, G. L'EuroQol-5D (EQ-5D): Uno strumento per la misura della qualità della vita. Monaldi Arch. Chest Dis. 2012, 78, 155-159. [CrossRef] [PubMed]

62. Feng, Y.; Parkin, D.; Devlin, N.J. Assessing the performance of the EQ-VAS in the NHS PROMs programme. Qual. Life Res. 2014, 23, 977-989. [CrossRef] [PubMed]

63. Diekmann, A.; Jann, B. Anreizformen und Ausschöpfungsquoten bei postalischen Befragungen: Eine Prüfung der Reziprozitätshypothese. ZUMA Nachr. 2001, 48, 18-27.

64. Petermann, S. Rücklauf und systematische Verzerrungen bei postalischen Befragungen: Eine Analyse der Bürgerumfrage Halle 2003. ZUMA Nach. 2005, 57, 55-78.

65. League of American Bicyclists. Bicycle Account Guidelines. 2013. Available online: http://bikeleague.org/ sites/default/files/Bicycle_Account_Guidelines.pdf (accessed on 23 January 2018).

66. New South Wales Government. Adult Population Health Survey. Forthcoming. Available online: http:/ / www.health.nsw.gov.au/surveys/adult/Pages/default.aspx (accessed on 23 January 2018). 
67. Universitätsklinikum Hamburg-Eppendorf. Hamburg City Health Study. Available online: http:/ /hchs. hamburg/ (accessed on 23 January 2018).

68. Schuster, C.; Honold, J.; Lauf, S.; Lakes, T. Urban heat stress: Novel survey suggests health and fitness as future avenue for research and adaptation strategies. Environ. Res. Lett. 2017, 12, 44021. [CrossRef]

69. Bechtel, B.; Schmidt, K. Floristic mapping data as a proxy for the mean Urban heat Island. Clim. Res. 2011, 49, 45-58. [CrossRef]

70. Boettcher, M.; Flagg, D.D.; Grawe, D.; Hoffmann, P.; Petrik, R.; Schlünzen, K.H.; Schoetter, R.; Teichert, N. Modelling impacts of urban developments and climate adaptation measures on summer climate of Hamburg. Urban Sci. 2018, submitted.

71. Stewart, I.D.; Oke, T.R. Local Climate Zones for Urban Temperature Studies. Bull. Am. Meteor. Soc. 2012, 93, 1879-1900. [CrossRef]

72. Kaveckis, G. Modeling Future Populations Vulnerability to Heat Waves in Greater Hamburg; Universität Hamburg: Hamburg, Germany, 2017.

73. Karten, T. GEWOS Institut für Stadt-, Regional- und Wohnungsforschung GmbH; Sozialmonitoring Integrierte Stadtteilentwicklung: Hamburg, Germany, 2017.

74. ISO. Acoustics-Assessment of Noiseannoyance by Means of Social and Socio-Acoustic Surveys. Available online: https: / /www.iso.org/standard/28630.html (accessed on 23 January 2018).

75. Heimann, D. Schallausbreitung unter Meteorologischen und Topografischen Gegebenheiten; Deutsches Zentrum für Luft- und Raumfahrt: Hamburg, Germany, 2003.

76. Müller, G.; Möser, M. Taschenbuch der Technischen Akustik; Springer: Berlin, Germany, 2004.

77. Piercy, J.E.; Embleton, T.F.; Sutherland, L.C. Review of noise propagation in the atmosphere. J. Acoust. Soc. Am. 1977, 61, 1403-1418. [CrossRef] [PubMed]

78. European Commission (EC). Directive 2002/49/EC of the European Parliament and of the Council of 25 June 2002 Relating to the Assessment and Management of Environmental Noise. Environmental Noise Directive; European Commission: Brussels, Belgium, 2002.

79. Federal Republic of Germany. Bekanntmachung der Vorläufigen Berechnungsverfahren für den Umgebungslärm nach § 5 Abs. 1 der Verordnung über die Lärmkartierung (34. BImSchV); Federal Republic of Germany: Berlin, Germany, 2006.

80. Schick, A. Schallbewertung. Grundlagen der Lärmforschung; Springer: Berlin/Heidelberg, Germany, 1990.

81. Freie und Hansestadt Hamburg. Transparenzportal Hamburg. Available online: http://transparenz. hamburg.de/ (accessed on 23 January 2018).

82. Mielck, A. Unterschiede bei Läarmbelastungen und Luftverschmutzungen nach dem Haushaltseinkommen. In Umweltgerechtigkeit. Die Soziale Verteilung von Umweltbelastungen; Bolte, G., Mielck, A., Eds.; Juventa: Weinheim, Germany, 2004; pp. 139-153.

83. Empirica. Städte Mit den HöChsten Mietpreisen für Wohnungen in Deutschland im 4. Quartal 2017 (in Euro pro Quadratmeter). In Statista-Das Statistik-Portal. Available online: https:/ / de.statista.com/ statistik/daten/studie/1885/umfrage/mietpreise-in-den-groessten-staedten-deutschlands/ (accessed on 23 January 2018).

84. Fyhri, A.; Klaeboe, R. Road traffic noise, sensitivity, annoyance and self-reported health-A structural equation model exercise. Environ. Int. 2009, 35, 91-97. [CrossRef] [PubMed]

85. Nijland, H.A.; Hartemink, S.; van Kamp, I.; van Wee, B. The influence of sensitivity for road traffic noise on residential location: Does it trigger a process of spatial selection? J. Acoust. Soc. Am. 2007, 122, 1595. [CrossRef] [PubMed]

86. Statistisches Amt für Hamburg und Schleswig-Holstein. Bevölkerung mit Migrationshintergrund in den Hamburger Stadtteilen Ende. 2016. Available online: https://www.statistik-nord.de/ fileadmin/Dokumente/Statistik_informiert_SPEZIAL/SI_SPEZIAL_V_2017_Korrektur.pdf (accessed on 23 January 2018).

87. Raddatz, L.; Mennis, J. Environmental Justice in Hamburg, Germany. Prof. Geogr. 2013, 65, 495-511. [CrossRef]

88. Brainard, J.S.; Jones, A.P.; Bateman, I.J.; Lovett, A.A. Exposure to Environmental Urban Noise Pollution in Birmingham, UK. Urban Stud. 2016, 41, 2581-2600. [CrossRef]

89. Fischer, M.M.; Getis, A. (Eds.) Handbook of Applied Spatial Analysis. Software Tools, Methods and Applications; Springer: Heidelberg, Germany, 2010. 
90. Statistisches Amt für Hamburg und Schleswig-Holstein. Lohn- und Einkommensstatistik in Hamburg 2013. 2017. Available online: https://www.statistik-nord.de/fileadmin/Dokumente/Statistik_informiert_ SPEZIAL/SI_SPEZIAL_VIII_2017.pdf (accessed on 23 January 2018).

91. Van Gerven, P.W.M.; Vos, H.; van Boxtel, M.P.J.; Janssen, S.A.; Miedema, H.M.E. Annoyance from environmental noise across the lifespan. J. Acoust. Soc. Am. 2009, 126, 187-194. [CrossRef] [PubMed]

92. Häder, M. Empirische Sozialforschung, 2nd ed.; Überarbeitete Auflage; VS Verl. für Sozialwiss: Wiesbaden, Germany, 2010.

93. Diekmann, A. Empirische Sozialforschung. Grundlagen, Methoden, Anwendungen; Rowohlt: Reinbek bei Hamburg, Germany, 2017.

94. Van Kamp, I.; Davies, H. Noise and health in vulnerable groups: A review. Noise Health 2013, 15, 153-159. [CrossRef] [PubMed]

95. Babisch, W.; Swart, W.; Houthuijs, D.; Selander, J.; Bluhm, G.; Pershagen, G.; Dimakopoulou, K.; Haralabidis, A.S.; Katsouyanni, K.; Davou, E.; et al. Exposure modifiers of the relationships of transportation noise with high blood pressure and noise annoyance. J. Acoust. Soc. Am. 2012, 132, 3788-3808. [CrossRef] [PubMed]

96. Babisch, W.; Pershagen, G.; Selander, J.; Houthuijs, D.; Breugelmans, O.; Cadum, E.; Vigna-Taglianti, F.; Katsouyanni, K.; Haralabidis, A.S.; Dimakopoulou, K.; et al. Noise annoyance-A modifier of the association between noise level and cardiovascular health. Sci. Total Environ. 2013, 452-453, 50-57. [CrossRef] [PubMed]

97. Miedema, H.M.E. Annoyance Caused by Environmental Noise: Elements for Evidence-Based Noise Policies. J. Soc. Issues 2007, 63, 41-57. [CrossRef]

98. Meyer-Wellmann, J. Bürgerschaft Beschließt Massiven Wohnungsbau an Hauptstraßen. Hamburger Abendblatt. Available online: https://www.abendblatt.de/hamburg/article212208285/Buergerschaftbeschliesst-massiven-Wohnungsbau-an-Hauptstrassen.html (accessed on 11 October 2017).

99. Asendorpf, D. (Interview) “Wenn Sie da Wohnen ... " Zeit Online. Available online: http:/ /www.zeit.de/ 2017/34/laerm-rainer-guski-lautstaerke (accessed on 16 August 2017).

100. Yang, Z.; Wang, S. The impact of privatization of public housing on housing affordability in Beijing: An assessment using household survey data. Local Econ. 2011, 26, 384-400. [CrossRef]

101. Lee, J.A. Rights at Risk in Privatized Public Housing. 2015. Available online: https://scholarworks.law. ubalt.edu/cgi/viewcontent.cgi?article=1391\&context=all_fac (accessed on 23 January 2018).

102. Twickel, C. Gentrifidingsbums. Oder Eine Stadt für Alle, 4th ed.; Nautilus: Hamburg, Germany, 2013.

103. Davoudi, S.; Atkinson, R. Social Exclusion and the British Planning System. Plan. Pract. Res. 1999, 14, 225-236. [CrossRef]

104. Walker, G.; Mitchell, G.; Fairburn, J.; Smith, G. Industrial pollution and social deprivation: Evidence and complexity in evaluating and responding to environmental inequality. Local Environ. 2007, 10, 361-377. [CrossRef]

105. Cutter, S.L. Race, class and environmental justice. Prog. Hum. Geogr. 2016, 19, 111-122. [CrossRef]

106. Speer, J. Henri Lefebvre: Spatial Politics, Everyday Life and the Right to the City. AAG Rev. Books 2015, 3, 4-5. [CrossRef]

107. Martens, K. Transport Justice. Designing Fair Transportation Systems; Routledge: London, UK, 2016.

108. Walker, G.; Bulkeley, H. Geographies of environmental justice. Geoforum 2006, 37, 655-659. [CrossRef]

109. Forkenbrock, D.J.; Sheeley, J. Effective Methods for Environmental Justice Assessment; NCHRP Report No. 532; Transportation Research Board: Washington, DC, USA, 2004.

110. Steven, H. Investigations on Noise Emission of Motor Vehicles in Road Traffic: Research Project 20054 135; Final Report; RWTUEV Fahrzeug GmbH—Institute for Vehicle Technology: Wuerselen, Germany, 2005.

111. Connolly Carmalt, J.; Faubion, T. Normative approaches to critical health geography. Prog. Hum. Geogr. 2010, 34, 292-308. [CrossRef]

112. Stephens, C. Revisiting urban health and social inequalities: The devil is in the detail and the solution is in all of us. Environ. Urban. 2011, 23, 29-40. [CrossRef]

113. Sicotte, D. Diversity and Intersectionality among Environmentally Burdened Communities in the Philadelphia Metropolitan Area, USA. Urban Stud. 2013, 51, 1850-1870. [CrossRef] 
114. Reckien, D.; Creutzig, F.; Fernandez, B.; Lwasa, S.; Tovar-Restrepo, M.; Mcevoy, D.; Satterthwaite, D. Climate change, equity and the Sustainable Development Goals: An urban perspective. Environ. Urban. 2017, 29, 159-182. [CrossRef]

115. Walker, G. Environmental justice, impact assessment and the politics of knowledge: The implications of assessing the social distribution of environmental outcomes. Environ. Impact Assess. Rev. 2010, 30, 312-318. [CrossRef]

(c)

(C) 2018 by the authors. Licensee MDPI, Basel, Switzerland. This article is an open access article distributed under the terms and conditions of the Creative Commons Attribution (CC BY) license (http://creativecommons.org/licenses/by/4.0/). 